\title{
Micronutrients impact the gut microbiota and blood glucose
}

\author{
Nicole G Barra, Fernando F Anhê, Joseph F Cavallari, Anita M Singh, Darryl Y Chan and Jonathan D Schertzer \\ Department of Biochemistry and Biomedical Sciences, Farncombe Family Digestive Health Research Institute, Centre for Metabolism, Obesity and \\ Diabetes Research, McMaster University, Hamilton, Ontario, Canada
}

\section{Correspondence should be addressed to J D Schertzer: schertze@mcmaster.ca}

This paper is part of a collection of articles exploring Gut Microbiome and Endocrinology, across the Journal of Endocrinology and the Journal of Molecular Endocrinology.

\begin{abstract}
Micronutrients influence hormone action and host metabolism. Dietary minerals, trace elements, and vitamins can alter blood glucose and cellular glucose metabolism, and several micronutrients are associated with the risk and progression of type 2 diabetes. Dietary components, microbes, and host immune, endocrine, and metabolic responses all interact in the intestine. There has been a focus on macronutrients modifying the host-microbe relationship in metabolic disease. Micronutrients are positioned to alter host-microbe symbiosis that participates in host endocrine control of glucose metabolism. Minerals and trace elements can alter the composition of the intestinal microbiota, gut barrier function, compartmentalized metabolic inflammation, cellular glucose transport, and endocrine control of glucose metabolism, including insulin and thyroid hormones. Dietary vitamins also influence the composition of the intestinal microbiota and vitamins can be biotransformed by gut microbes. Host-microbe regulation of vitamins can alter immunity, lipid and glucose metabolism, and cell fate and function of pancreatic beta cells. Causal effects of micronutrients in host-microbe metabolism are still emerging, and the mechanisms linking dietary excess or deficiency of specific micronutrients to changes in gut microbes directly linked to metabolic disease risk are not yet clear. Dietary fiber, fat, protein, and carbohydrates are key dietary factors that impact how microbes participate in host glucose metabolism. It is possible that micronutrient and microbiota-derived factors also participate in host-microbe responses that tip the balance in the endocrine control of host glucose metabolism. Dietary micronutrients should be considered, tested, and controlled in pre-clinical and clinical studies investigating host-microbe factors in metabolic diseases.
\end{abstract}
Key Words
- intestinal
- microbiome
- nutrition
- diabetes
- lipid
- insulin
- resistance
- glucose

Journal of Endocrinology (2021) 250, R1-R21

\section{Introduction}

There is interest in understanding the impact of composition and function of intestinal-resident bacterial communities (i.e. the gut microbiota) on host metabolism. A major challenge is ascribing function to bacterial communities, strains, and metabolites and how each influences aspects of host metabolism. In addition, determining directionality in the hostmicrobe relationship that leads to actionable outcomes in metabolic disease is an important challenge. It is critical to determine the environmental factors and host 
characteristics that influence host-microbe relationships in metabolic health and disease. Many factors shape the microbial ecosystems residing within different intestinal and tissue compartments, and bacteria or bacterial components that penetrate host extra-intestinal tissues (Gérard 2016, Anhê et al. 2020a). The intestine harbors the majority of commensal microbes in humans. Nutrients, bacteria, and host cells that direct immune, endocrine, and metabolic responses directly interact within the intestinal environment (Thursby \& Juge 2017). Given that diet is a key factor in metabolic diseases, it is important to understand how dietary components interact and alter the connections between microbes and host immunity and metabolism. It is known and well-characterized that macronutrients and fiber can alter the composition of the intestinal microbiota. In this review, we will summarize how micronutrients can influence the community composition and possibly the function of the microbiota, which relay signals that impact host metabolism and metabolic disease like obesity. Uncovering the complex relationship between diet, gut bacteria, and host metabolism may reveal aspects of how obesity worsens blood glucose control. This review focuses on how micronutrients influence host glucose metabolism by altering the host-microbe relationship.

\section{Gut microbes and metabolic disease}

Modifying the composition of the gut microbiota can impact metabolism. For example, low-dose antibiotic administration during a critical window of development can increase body mass, which persists later in life in livestock and mice (Cox et al. 2014). Sub-therapeutic antibiotic treatment in the early life of mice altered gut microbial composition, increased microbial metabolites such as short-chain fatty acid (SCFA) levels in the colon, increased adipose tissue mass, and changed hepatic gene expression related to carbohydrate and lipid metabolism (Cho et al. 2012).

Studies using rodents that are born with no bacteria have revealed some of the bacterial contributions to host metabolism. Germ-free mice extract less energy from food, demonstrating that bacteria regulate intestinal energy extraction. Microbial influence on digestion and intestinal absorption of dietary components and energy content is a key mechanism by which bacteria influence energy balance (Bäckhed et al. 2004). Metabolic disease states, like obesity, can alter the gut microbiota to promote more energy extraction from food (Bäckhed et al. 2007).
The gut microbiota can also influence blood glucose. Lower bacterial diversity correlates with insulin resistance and higher adiposity (reviewed in Zhu \& Goodarzi 2020). Type 2 diabetes (T2D) is associated with an altered composition of the gut microbiota, where the lower relative abundance of Firmicutes Clostridia, but higher Betaproteobacteria in diabetic humans was associated with higher blood glucose. There are many correlations between taxonomy and possible host functions. For example, the Firmicutes phylum consists predominantly of SCFA butyrate-producing bacteria; specifically, certain Clostridia have anti-inflammatory properties and are less abundant in individuals with T2D. Faecalibacterium prausnitzii is another butyrate-producing strain that is associated with improvements in glucose tolerance in patients who have undergone gastric bypass surgery, suggesting that bacterial metabolites can also affect glucose homeostasis. In addition, branched-chain amino acids produced by Bacteroides vulgatus species positively correlate with insulin resistance (Pedersen et al. 2016, Zhu \& Goodarzi 2020). Lastly, the commonly prescribed glucose-lowering agent metformin in T2D can alter gut microbes by increasing SCFAproducing bacteria and mucin-degrading Akkermansia muciniphila while increasing intestinal glucose absorption and glucagon-like peptide-1 production (McCreight et al . 2016, Vallianou et al. 2019). Although there are fewer examples of microbes or microbial communities causing changes in blood glucose, the microbiota from obese mice can transmit higher blood glucose into germ-free mice independently of changes in adiposity (Foley et al. 2018).

Overall, this supports the concept that the microbiota participates in host blood glucose control. Diet is a major factor in shaping the composition and function of the gut microbiota. The effects of dietary fiber and macronutrients on the gut microbiota are rapid and reproducible (David et al. 2014). The purpose of this review is to highlight the state of knowledge for micronutrients altering the hostmicrobe relationship relevant to host glucose metabolism.

\section{Macronutrients and gut microbes}

Diet composition continuously shapes the gut microbiota, in a bidirectional relationship between bacterial composition/function and dietary components (Rinninella et al. 2019). Although the human gut microbiota is largely dominated by two key phyla, Firmicutes and Bacteroidetes, shifts in the relative abundance of these and less abundant phyla due to altered diet can impact host immunity and metabolism (Rinninella et al. 2019). 
Macronutrients including fats, carbohydrates, and proteins provide most of the energy content of food, and each is processed to varying degrees by both host and gut microbes.

Fats are the most energy-dense macronutrient and an efficient means to store energy. Excess intake of dietary fat alters the composition of the intestinal microbiota disrupting host-microbe equilibrium (i.e. dysbiosis), fueling pro-inflammatory responses in the host, and, therefore, contributes to obesity and insulin resistance (Cândido et al. 2018, Bisanz et al. 2019). The importance of dietary fat on the composition of gut microbiota and consequences for metabolic disease are well-reviewed (Shen et al. 2014).

Carbohydrates are another important dietary macronutrient that are particularly important in altering blood glucose. Carbohydrates can be generally classified into digestible and indigestible. The former is easily processed by the host for energy, whereas the latter can be processed by gut bacteria (Chassard \& Lacroix 2013). The topic of carbohydrates and gut microbiota is also well-described (Chassard \& Lacroix 2013). Dietary fiber is a subcategory of fermentable and non-fermentable indigestible carbohydrates that has a major impact on the composition and function of the gut microbiota (Dalby et al. 2017, Makki et al. 2018).

Dietary protein content influences the composition of the gut microbiota and simultaneously, gut bacteria can help biotransform dietary protein. Sources of protein (i.e. animal vs plant), the amino acid composition of proteins, and consumed quantities can all affect bacterial amino acid metabolism and metabolite production. In addition, recent evidence demonstrated that modifying protein from casein to a bacterial-derived source of protein during feeding of a high fat and high sugar diet can reverse western diet-induced gut bacterial changes and improve insulin sensitivity (Jensen et al. 2021). The plethora of variables involved in protein metabolism can have significant consequences for host health and disease and have been reviewed elsewhere (Zhao et al. 2019).

\section{Micronutrients: minerals, trace elements, gut microbes, and glucose metabolism}

Dietary intake of trace minerals and vitamins are required in smaller amounts compared to macronutrients (generally in the milligram range), but its intake is critical for the regulation of many physiological processes, including metabolism. In general, trace minerals, also referred to as trace elements, make up less than $0.01 \%$ of the total body weight or are required in amounts between
1 and $100 \mathrm{mg} /$ day in adults (Mehri 2020). Vitamins are organic compounds that are water or fat-soluble and can be essential micronutrients (Lykstad \& Sharma 2020). A summary outlining the effects of trace elements on gut bacteria and host metabolism is provided in Tables 1 , 2 and 3.

\section{Chromium}

Chromium exists either in the most stable oxidation trivalent (3+) state found in food or the strongly oxidizing hexavalent (6+) state generated from industrial pollution. Inorganic chromium exists in the soil. Plants secrete organic acids that can act as carrier molecules, therefore increasing the solubility and promoting the uptake and conversion of inorganic chromium into its organic form (Sharma et al. 2020). Food sources of chromium include meats, whole grains, fruits, vegetables, and spices (National Institutes of Health 2020a). Chromium supplementation in individuals with T2D is associated with improved blood glucose control (Paiva et al. 2015). Supplementing high fatfed mice with chromium reduced body weight, lowered hepatic and circulating triglycerides, and improved insulin sensitivity by increasing hepatic insulin signaling (Chen et al. 2010). In addition, chromium restriction in utero promotes glucose intolerance, hyperglycemia, hyperinsulinemia, and insulin resistance in adult murine offspring (Zhang et al. 2016). Finally, a recent meta-analysis showed that chromium supplementation lowers fasting plasma glucose, hemoglobin A1c, and triglyceride levels while increasing circulating high-density lipoprotein (HDL) cholesterol in type 2 diabetic patients (Huang et al. 2018). Altogether, these results demonstrate an association of chromium with blood glucose.

The link between chromium and the gut microbiota is starting to emerge. Chromium supplementation using a probiotic strain (Bacillus subtilis) in mice promoted insulin secretion and lowered blood glucose, which was associated with higher skeletal muscle insulin receptor levels, and an improved circulating lipid profile (Yang et al. 2016). Although inorganic chromium caused some of these metabolic effects, supplementation with probioticproduced organic chromium had greater metabolic outcomes (Yang et al. 2016). Therefore, the bioavailability and/or biological activity of chromium is an important determinant for its metabolic effects, with the gut microbiota positioned to relay these divergent metabolic effects. Organic and inorganic forms of chromium have different effects on intestinal flora. Compared to inorganic chromium, organic chromium supplementation increased 
Table 1 The effects of non-metal trace elements on the gut microbiome and host metabolism.

\begin{tabular}{|c|c|c|c|}
\hline Trace element & $\begin{array}{l}\text { Recommended dietary } \\
\text { allowance (RDA) }\end{array}$ & Effects on gut microbiome & Effect on metabolism \\
\hline Fluoride (F) & $\begin{array}{l}\text { Male: } 4 \mathrm{mg}{ }^{\wedge} \\
\text { Female: } 3 \mathrm{mg} \wedge \\
\text { Pregnant: } 3 \mathrm{mg} \wedge \\
\text { Lactation: } 3 \mathrm{mg} \wedge\end{array}$ & 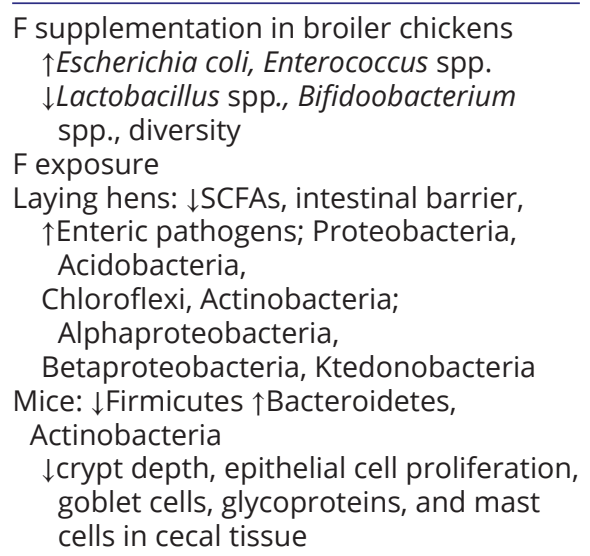 & $\begin{array}{l}\text { F supplementation: } \\
\uparrow \text { insulin sensitivity, hepatic GLUT } 4 \\
\downarrow \text { Hepatic PEPCK, gluconeogenesis } \\
\downarrow \text { APO-E } \rightarrow \downarrow \text { cholesterol biosynthesis (LDL } \\
\text { and total cholesterol } \\
\text { High F doses: } \\
\text { Hyperinsulinemia, IR, glucose intolerance (in } \\
\text { rats with renal deficiency (1-15 ppm)), } \\
\text { impaired insulin signaling }\end{array}$ \\
\hline lodine (I) & $\begin{array}{l}\text { Male: } 150 \mu \mathrm{g} \\
\text { Female: } 150 \mu \mathrm{g} \\
\text { Pregnant: } 220 \mu \mathrm{g} \\
\text { Lactation: } 290 \mu \mathrm{g}\end{array}$ & $\begin{array}{l}\text { HF-fed I-supplemented vs HF-control mice: } \\
\uparrow \text { Bacterial species of Enterococcus, } \\
\text { Clostridium, and Fusobacterium } \\
\text { nucleatum } \\
\text { } \text { enteric pathogenic bacteria } \\
\downarrow \text { Faecalibacterium prausnizii, } \\
\text { Lactobacillus, and Bifidobacterium } \\
\text { Supplementation, independent of fat } \\
\uparrow \text { Oscillibacter, Allobaculum: } \downarrow \text { Blautia }\end{array}$ & $\begin{array}{l}\text { Deficient and excess status linked to T2DM } \\
\text { Supplementation: } \\
\downarrow \text { BW, adiposity, liver weight } \\
\text { †blood thyroid hormone (TSH, TT3, FT3, FT4) } \\
\text { High I dose: } \\
\text { Pancreatic destruction, hyperglycemia } \\
\text { Impair beta cell insulin secretion, apoptosis }\end{array}$ \\
\hline Selenium (Se) & $\begin{array}{l}\text { Male: } 55 \mu \mathrm{g} \\
\text { Female: } 55 \mu \mathrm{g} \\
\text { Pregnant: } 60 \mu \mathrm{g} \\
\text { Lactation: } 70 \mu \mathrm{g}\end{array}$ & $\begin{array}{l}\text { Decreased Se associated with IBD } \\
\text { Se supplementation in broiler chickens: } \\
\downarrow \text { Enteric pathogens; mitigates } \\
\text { Ochratoxin-induced } \downarrow \alpha \text {-diversity, } \\
\text { oxidative stress, inflammation }\end{array}$ & $\begin{array}{l}\text { Deficient and excess status linked to IR, T2DM; } \\
\text { hepatokine selenoprotein P linked to IR } \\
\text { Se Supplementation in CHF and diabetic CHD } \\
\downarrow \text { serum insulin, HOMA-IR, LDL, CRP } \\
\uparrow H D L, \text { insulin sensitivity, antioxidant levels; } \\
\downarrow \text { Beta cell oxidative damage and H2O2 } \\
\text { induced insulin signaling. }\end{array}$ \\
\hline
\end{tabular}

RDA values based on adults aged 19-50 years old.

$\wedge$ Adequate intake (Al) values are given for $F$.

ALT, alanine transaminase; APO-E, apolipoprotein E; AST, aspartate aminotransferase; BW, body weight; CHF, congestive heart failure; CHD, coronary heart disease; FBG, fasting blood glucose; FT3, free triiodothyronine (T3); FT4, free thyroxine (T4); HDL, high density lipoprotein; HbA1c, hemoglobin A1 c; HF, high fat; HTN, hypertension; IBD, inflammatory bowel disease; IR, insulin resistance; Kdo, keto-deoxyoctulosonate; LDL, low density lipoprotein; LPS, lipopolysaccharide; NAFLD, non-alcoholic fatty liver disease; PTEN, phosphatase and tensin homolog protein; RIP3, receptor-interacting protein kinase 3 ; s.c., subcutaneously; SCFA, short chain fatty acids; T2M, type 2 diabetes; TAG, triacylglycerol; TSH, thyroid-stimulating hormone; TT3, total triiodothyronine (T3); wks, weeks.

the number of gram-positive bacteria in type 2 diabetic rats, which correlated with improved insulin sensitivity and circulating cardiovascular measures (Feng et al. 2015) (Fig. 1). The carrier molecule is also a critical characteristic contributing to diverging metabolic effects since rats administered chromium malate had increased grampositive bacteria and decreased gram-negative bacteria compared to administration of chromium picolinate (Feng et al. 2015). Microbial changes correlating with chromium malate coincided with lower fasting blood glucose, circulating triglycerides, and total/LDL cholesterol (Feng et al. 2015) (Fig. 1). The metabolic effects of organic chromium malate were greater than any other chromium source tested in a type 2 diabetic rat model, suggesting that the type of chromium and its relationship with the gut

(c) 2021 Society for Endocrinology Published by Bioscientifica Ltd. Printed in Great Britain microbiota should be considered regarding the metabolic impact of this micronutrient. Overall, these results demonstrate the effects of chromium on the gut microbiota and host metabolism are dependent on the organic vs inorganic source of this trace element and the compound it is attached to, which may influence its bioavailability, therefore impacting the host-microbe relationship.

\section{Copper}

Copper is involved in many enzymatic and oxidationreduction reactions. Dietary sources of copper include nuts, shellfish, whole-grain products, mushrooms, and tofu (National Institutes of Health 2019). Higher circulating copper levels are associated with impaired blood glucose 
Table 2 The effects of transition metal trace elements on the gut microbiome and host metabolism.

\begin{tabular}{|c|c|c|c|}
\hline Trace element & $\begin{array}{l}\text { Recommended dietary } \\
\text { allowance (RDA) }\end{array}$ & Effects on gut microbiome & Effect on metabolism \\
\hline Chromium (Cr) & $\begin{array}{l}\text { Male: } 35 \mu g \wedge \\
\text { Female: } 25 \mu g^{\wedge} \\
\text { Pregnant: } 30 \mu g^{\wedge} \\
\text { Lactation: } 45 \mu g^{\wedge}\end{array}$ & $\begin{array}{l}\text { Probiotic B. subtilis Cr in mice } \\
\quad \uparrow \text { Cecal Lactobacillus, Bifidobacterium } \\
\downarrow \text { Escherichia coli, Staphylococcus } \\
\text { Organic vs Inorganic Cr supplementation } \\
\text { in rats } \\
\text { Organic Cr improved insulin sensitivity, } \\
\uparrow \text { Fecal Gram positive bacteria vs inorganic Cr } \\
\uparrow \text { Fecal Gram positive bacteria, } \downarrow \text { Gram } \\
\text { negative cocci in Cr Malate vs Cr Picolinate }\end{array}$ & $\begin{array}{l}\text { Probiotic } B \text {. subtilis } \mathrm{Cr} \text { in mice } \\
\uparrow \mathrm{HDL} \text {, Insulin } \\
\downarrow \mathrm{LDL} \text {, total cholesterol, TAGs, Glucose } \\
\text { Cr supplementation } \\
\text { HF-fed mice: } \downarrow \text { BW, hepatic TAGs, IR } \\
\text { Diabetics: } \downarrow \text { FBG, HbA1C, TAGs; } \uparrow \mathrm{HDL} \\
\text { Cr restriction (In utero) } \\
\text { Glucose intolerance, } \\
\text { hyperinsulinemia, IR }\end{array}$ \\
\hline Copper (Cu) & $\begin{array}{l}\text { Male: } 900 \mu \mathrm{g} \\
\text { Female: } 900 \mu \mathrm{g} \\
\text { Pregnant: } 1.3 \mathrm{mg} \\
\text { Lactation: } 1.3 \mathrm{mg}\end{array}$ & $\begin{array}{l}\text { Increased Cu associated with IBD } \\
\text { Different Cu sources on gut microbiota } \\
\text { Rats: Cu-Chitosan Nanoparticle } \downarrow \text { Salmonella, } \\
\text { Clostridium } \uparrow \text { Lactobacilli SCFAs vs Cu sulfate } \\
\text { Rats: Probiotic Cu delivery } \uparrow \text { Lachnospiraceae, } \\
\text { Ruminococcaeae, Intestinibacter } \\
\text { High Cu exposure } \\
\text { Pigs: } \downarrow \text { Clostridia, Roseburia, Acidaminococcus, } \\
\text { Coprococcus; } \uparrow F i b r o b a c t e r e s \\
\text { Carp: } \downarrow \text { Lactobacillus, Bacillus, and Akkermansia; } \\
\uparrow \text { Pathogens, } \downarrow \text { growth indices, tight junction }\end{array}$ & $\begin{array}{l}\text { High circulating levels correlates to T2DM } \\
\text { Copper bound to ceruloplasmin } \\
\text { positively correlates with IR, BMI, } \\
\text { T2DM risk } \\
\text { High Cu diets } \rightarrow \text { enhanced hepatic } \\
\text { lipid/TAG content, lipogenic genes } \\
\text { Marginal Cu diets + fructose } \rightarrow \text { NAFLD } \\
\text { development }\end{array}$ \\
\hline Manganese (Mn) & $\begin{array}{l}\text { Male: } 2.3 \mathrm{mg}{ }^{\wedge} \\
\text { Female: } 1.8 \mathrm{mg} \\
\text { Pregnant: } 2.0 \mathrm{mg} \\
\text { Lactation: } 2.6 \mathrm{mg}^{\wedge}\end{array}$ & $\begin{array}{l}\text { Low levels associated with IBD (in hair) } \\
\text { In DSS-colitis Mn-deficient mice } \\
\uparrow \text { Morbidity, weight loss, colon injury, } \\
\text { inflammatory cytokines, oxidative and DNA } \\
\text { damage; intestinal permeability } \\
\text { Sex-specific differences in mice (Male vs Female) } \\
\text { Bacteroidetes: } \downarrow \text { Male } \uparrow F e m a l e \\
\text { Verrumicrobia: } \downarrow \text { Male } \uparrow F e m a l e \\
\text { Firmicutes: } \downarrow \text { Male } \uparrow \text { Female } \\
\downarrow M \uparrow F: \text { bacterial genes: phenylalanine } \\
\text { synthesis, endotoxin biogenesis, oxidative } \\
\text { stress/DNA }\end{array}$ & $\begin{array}{l}\text { Deficient and excess status linked to IR, } \\
\text { glucose intolerance, increased } \\
\text { T2DM risk } \\
\text { Mn supplementation } \\
\text { †insulin production } \\
\text { } \text { antioxidant activity } \\
\downarrow \text { pancreatic oxidative stress, renal } \\
\text { lipid peroxidation and HTN }\end{array}$ \\
\hline
\end{tabular}

RDA values based on adults aged 19-50 years old.

$\wedge$ Adequate intake (Al) values are given for $\mathrm{Cr}$ and $\mathrm{Mn}$.

control and risk of T2D (Yin et al. 2019). In addition, copper-carrying proteins, such as ceruloplasmin, positively correlate with insulin resistance in subjects at increased diabetes risk (Aguilar et al. 2013). Lifestyle modifications such as caloric restriction and physical exercise are associated with lower circulating levels of copper bound to ceruloplasmin in people that are overweight (Piacenza et al. 2015). Overall, these results show a correlation between higher circulating copper levels and worse blood glucose control. However, the mechanisms of copper's action in animal and in vitro models have not clearly defined how this micronutrient influences blood glucose, which may involve pancreatic beta-cell dysfunction and/or peripheral insulin action (Miller et al. 1998, Sitasawad et al. 2001, Ward et al. 2008, Seal \& Dey 2018).

Increased circulating copper levels are associated with inflammatory conditions including inflammatory bowel disease (IBD), which may reveal some mechanisms relevant to the influence of copper on the connection between obesity-inflammation-microbiota and blood glucose control (Stochel-Gaudyn et al. 2019) (Fig. 2). Copper deficient diets can negatively impact the intestinal barrier by reducing the expression of ileal tight junction proteins like CLAUDIN-1 and OCCLUDIN (Song et al. 2018). Dietary copper alters the abundance of over 20 metabolites including fatty acids (eladic acid, stearic acid, pentadecylic acid) and amino acids (L-threonine, L-aspartic acid, L-proline) in the feces of rats (Wei et al. 2015). Dietary copper also alters the abundance of Firmicutes and Verrucomicrobia at the phylum level; Lactobacillaceae, Eubacteriaceae, Ruminococcaceae, Erysipelotrichaceae, and Verrucomicrobiaceae at the family level, and Lactobacillus, Coprococcus, Oscillospira, Allobaculum, and Akkermansia at the genus level (Song et al. 2018). Elevated copper exposure in pufferfish alters the composition of the gut microbiota which correlates with higher hepatic expression of lipogenic genes and higher liver lipid content (Wang et al. 2019a) (Fig. 2). Altogether, these data suggest that dietary 
Table 3 The effects of transition metal trace elements on the gut microbiome and host metabolism.

\begin{tabular}{|c|c|c|c|}
\hline Trace element & $\begin{array}{l}\text { Recommended dietary } \\
\text { allowance (RDA) }\end{array}$ & Effects on gut microbiome & Effect on metabolism \\
\hline$\overline{\text { Molybdenum (Mo) }}$ & $\begin{array}{l}\text { Male: } 45 \mu \mathrm{g} \\
\text { Female: } 45 \mu \mathrm{g} \\
\text { Pregnant: } 50 \mu \mathrm{g} \\
\text { Lactation: } 50 \mu \mathrm{g}\end{array}$ & $\begin{array}{l}\text { High supplementation (100 mg/kg) in } \\
\text { laying hens } \\
\downarrow \text { Firmicutes } \uparrow \text { Proteobacteria } \\
\uparrow \text { Deltaproteobacteria, Mytococcales, } \\
\text { Nanocystaceae } \\
\uparrow \text { circulating ALT, AST } \\
\text { Acts as a bacterial cofactor } \\
\text { Dehydroxylation by E. lenta in Levodopa } \\
\text { metabolism } \\
\text { Promotes metabolism and overgrowth of } E \text {. } \\
\text { coli in DSS-colitis murine model }\end{array}$ & $\begin{array}{l}\text { Positive correlation with T2DM, IR, FBG, } \\
\text { glucose intolerance in humans } \\
\downarrow \text { Mo associated with NAFLD risk in } \\
\text { humans } \\
\text { Mo supplementation } \\
\text { } \text { glucose tolerance, glycemia in ob/ob } \\
\text { mice } \\
\text { Prevents hepatic lipid accumulation and } \\
\text { oxidative stress }\end{array}$ \\
\hline Zinc (Zn) & $\begin{array}{l}\text { Male: } 11 \mathrm{mg} \\
\text { Female: } 8 \mathrm{mg} \\
\text { Pregnant: } 11 \mathrm{mg} \\
\text { Lactation: } 12 \mathrm{mg}\end{array}$ & $\begin{array}{l}\text { Decreased Zn associated with IBD } \\
\text { Zn status linked to enteric infection } \\
\text { Deficiency enhanced Shigella flexneri } \\
\text { colonization } \\
\text { Supplemented S. typhimurium infected } \\
\text { broiler chickens mitigated } \downarrow \text { Lactobacillus, } \\
\text { total bacteria } \\
\text { Excess Zn increase susceptibility to } C \text {. } \\
\text { difficile, } \downarrow \alpha \text {-diversity, Turicibacter, } \uparrow \\
\text { Enterococcus, Clostridium } \\
\text { Excess Zn } \uparrow P \text { Pathogenic taxa, intestinal } \\
\text { permeability and systemic inflammation } \\
\text { Zn deficient Broiler chickens: } \\
\downarrow \text { microbial richness, diversity, } \\
\downarrow \text { Firmicutes } \uparrow \text { Proteobacteria, } \\
\text { Enterobacteriaceae } \\
\downarrow \text { pathway expression: mineral absorption, } \\
\text { carbohydrate digestion and } \\
\text { fermentation } \downarrow S C F A\end{array}$ & 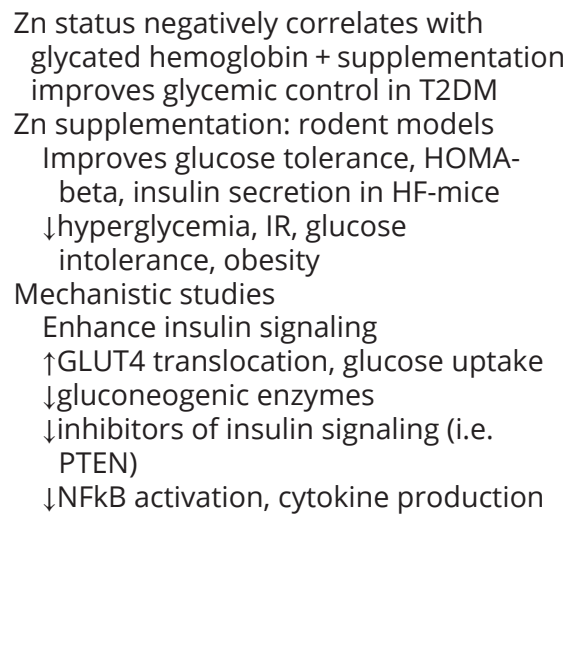 \\
\hline
\end{tabular}

RDA values based on adults aged 19-50 years old.

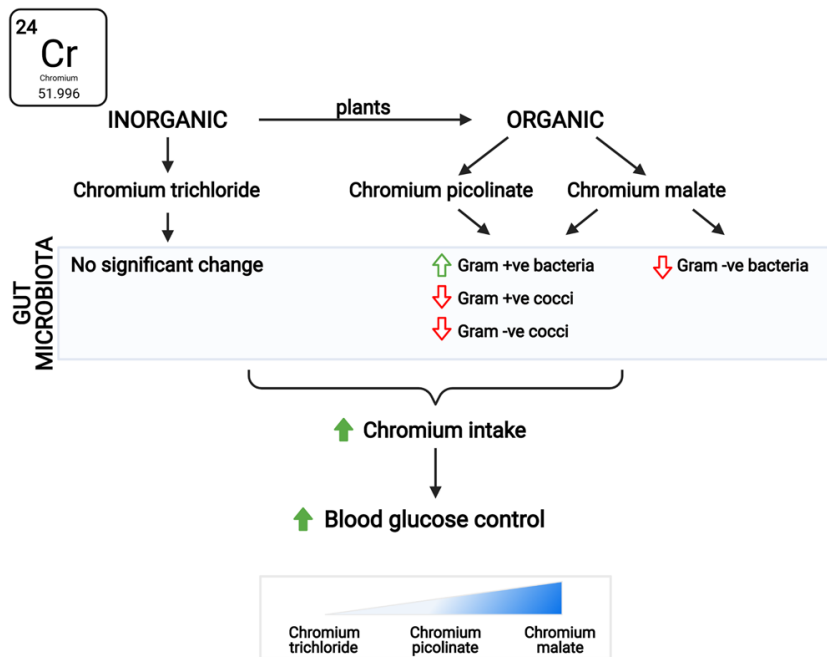

Figure 1

Chromium supplementation improves blood glucose control and alters gut microbes. Image created with BioRender.com.

(c) 2021 Society for Endocrinology Published by Bioscientifica Ltd. Printed in Great Britain copper influences gut microbiota, microbial metabolites, and host metabolism, particularly hepatic lipid content, which may provide a link between this micronutrient, gut bacteria, and blood glucose control.

In some countries, copper is added to livestock feed for its antimicrobial and growth-promoting traits. Administration of copper complexed to chitosan nanoparticles in rats decreased potentially pathogenic cecal bacteria (Salmonella, Clostridium) while increasing the abundance of bacteria with probiotic potential within the genus Lactobacillus, which did not occur in rats given copper sulfate (Han et al. 2010). Similarly, Bacillus subtilis bound to copper administered orally to pregnant and lactating rats enhanced the offspring's survival rate, body weight gain, and development of duodenal villi compared to rats given copper sulfate. These results were associated with reduced intestinal permeability and increased abundance of cecal Lachnospiraceae, Ruminococcaeae, and Intestinibacter (Liu et al. 2019a). Although copper supplementation decreased colonic Streptococci spp. in piglets, delivery of copper sulfate with and without a microencapsulated protective 

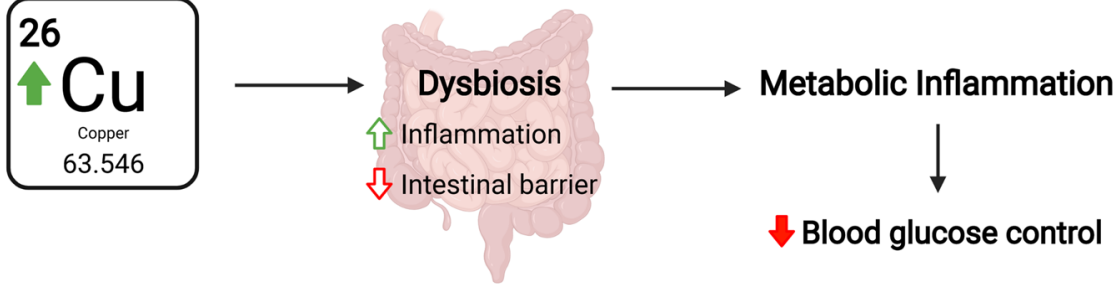

Blood glucose control

\section{Figure 2}

High dietary copper ingestion promotes dysbiosis, intestinal inflammation, and a compromised intestinal barrier contributing to poor glucose control. Image created with BioRender.com. matrix had different effects on the gut microbiota. Animals given encapsulated copper had reduced total bacteria and Enterobacteriaceae bacterial cecal counts compared to those receiving unprotected copper (Di Giancamillo et al. 2018). In sum, these findings demonstrate different sources of dietary copper and vehicles used to deliver copper can exert unique effects on the gut microbiota.

High dietary copper resulted in the reduction of several Clostridia genera and butyrate-producing bacteria such as Roseburia, Acidaminococcus, and Coprococcus, and increased Fibrobacteres, which was associated with changes in protein biosynthesis, gluconeogenesis, amino acid metabolism, galactose metabolism, and protein and carbohydrate metabolites in piglets (Zhang et al. 2019). Copper can also decrease SCFA-producing bacteria, and Lactobacillus, Bacillus, and Akkermansia, and increase the abundance of pathogens like Pseudomonas and Acinetobacter in carp exposed to different doses of this micronutrient. Higher copper exposure was associated with reduced growth indices and expression of intestinal tight junction proteins (Meng et al. 2018). Finally, excess dietary copper in mice reduced the abundance of bacteria genera Staphylococcus, Rikenella, and Jeotgailcoccus, but increased the relative abundance of Corynebacterium, which was associated with pathological intestinal lesions (Ruan et al. 2019). Overall, these results highlight that dietary copper can alter gut microbiota, inflammation, and barrier function that may set up for metabolic inflammation and poor blood glucose control.

\section{Fluoride}

Fluoride is added to tap water in most community water systems and dental hygiene products (Whitford 1994). The effect of fluoride on glucose homeostasis is dosedependent. Fluoride supplementation can increase insulin sensitivity, which may involve the regulation of hepatic glucose transporters (Lobo et al. 2015). Fluoride supplementation can also lower hepatic phosphoenolpyruvate carboxykinase (PEPCK), which is involved in gluconeogenesis (Trevizol et al. 2020). Despite these metabolic improvements with supplementation, high fluoride exposure can impair insulin signaling by reducing IRS-1/IRS-2 tyrosine phosphorylation while increasing serine phosphorylation in insulin-responsive tissue, promoting insulin resistance (Chiba et al. 2012).

Epidemiological studies suggest that fluoride exposure may be linked with gut inflammation and IBD (reviewed Follin-Arbelet \& Moum 2016), but few studies have examined the link between fluoride exposure and gut microbiota. Laying hens exposed to high fluoride (1200 mg/kg) had lower cecal SCFA concentration, impaired intestinal barrier function, and substantial changes to the gut microbiota including (1) higher relative abundance of enteric poultry pathogens like Chloroflexi, Stretococcaceae, Gammaproteobacteria, Enterobacter, and Escherichia shigella; (2) increased Proteobacteria, Acidobacteria, Chloroflexi, and Actinobacteria at the phylum level and (3) enhanced abundance of Alphaproteobacteria, Betaproteobacteria, Ktedonobacteria, and Gammaproteobacteria at the class level (Miao et al. 2020). In mice, fluoride added to water increased the relative abundance of Bacteroidetes and Actinobacteria and decreased Firmicutes. These fluoride-induced microbial changes were associated with histological gut abnormalities including evidence of a damaged epithelial barrier, decreased crypt depth, and lower epithelial cell proliferation, relative densities of goblet cells, glycoproteins, and intestinal mast cells (Liu et al. 2019b). However, one study in mice found no significant shifts in gut microbial community composition with a lower dose and shorter duration of fluoride added to water (Yasuda et al. 2017). Therefore, fluoride can alter the intestinal microbiota and gut health in ways that may influence blood glucose, but the dose and duration of fluoride are key factors to consider.

\section{lodine}

Iodine is an essential micronutrient involved in thyroid hormone synthesis. Thyroid hormone is critical to 
growth and development, along with multiple metabolic processes including lipid, protein, carbohydrate, vitamin, and mineral metabolism (reviewed in Mehri 2020). Iodine is generally obtained through the consumption of fish, seafood, dairy, and iodized salt (National Institutes of Health 2020b). The role of iodine in glucose homeostasis is primarily linked to thyroid hormone production and function. Both hyperthyroid and hypothyroid conditions are linked to insulin resistance (Maratou et al. 2009, 2010). Both iodine deficiency and excess are associated with increased risk of T2D (Mancini et al. 2019, Karakaya et al. 2020). In thyroidectomized rats, lower circulating thyroid hormone promotes glucose intolerance, which was mitigated with iodine-containing hormone thyroxine treatment (Samadi et al. 2017). However, higher doses of iodine result in pancreatic toxicity destruction of insulinsecreting beta cells, and hyperglycemia (Sarkar et al. 2018). Excess iodine exposure may impair pancreatic beta-cell insulin secretion and promote apoptosis through the activation of endoplasmic reticulum stress and induction of pro-apoptotic proteins (Sun et al. 2017). Overall, these studies demonstrate that both deficiency or excess iodine is associated with glucose intolerance primarily through effects on thyroid hormones and pancreatic insulin secretion.

Excess iodine in mice can increase adiposity, body weight, and liver weight, with variability in circulating thyroid hormones, including decreased total $\mathrm{T} 4$ and thyroid-stimulating hormone and increased free $\mathrm{T} 3$ and T4 (Shen et al. 2019). However, obesity may influence the effects of iodine supplementation. Excess iodine in obese high-fat diet mice resulted in weight loss, reduced adiposity and liver weight, and increased circulating thyroid hormone concentrations. Oral iodine supplementation altered the gut flora in obese high-fat fed and lean mice (Shen et al. 2019). Iodine supplementation increased the relative abundance of Oscillibacter and Allobaculum and decreased Blautia in both lean and obese mice. However, some effects of iodine were specific to the gut microbiota of obese mice, where iodine increased the relative abundance of Enterococcus, Clostridium, and Fusobacterium nucleatum, and pathogenic bacteria such as Burkholderiales and Helicobacter. Iodine supplementation decreased Faecalibacterium prausnizii, Lactobacillus, and Bifidobacterium in high-fat fed mice. These findings demonstrate that iodine supplementation can alter host metabolism and the composition of the gut microbiome, where obesity or dietary lipids influence the effect of iodine (Shen et al. 2019).

\section{Manganese}

Whole grains, nuts, legumes, and leafy vegetables contain manganese. As a cofactor, manganese participates in processes involved in blood glucose regulation, blood coagulation and hemostasis, and bone growth (Horning et al. 2015). Manganese is also involved in antioxidant production and can participate in responses that lower oxidative stress related to elevated blood glucose and lipids (Horning et al. 2015). Manganese deficiency and excess are both linked to insulin resistance, impaired glucose tolerance, and increased risk of T2D, which may occur in a sex-dependent manner (Shan et al. 2016, Yang et al. 2020a). Higher urinary manganese has a linear relationship with HbA1c and fasting blood glucose in women, but urinary manganese has a J-shaped dose-response relationship with insulin resistance and blood insulin in men (Yang et al. 2020a). In addition, high manganese blood levels were reported in obese children (Fan et al. 2017). Blood glucose may influence how manganese is processed since urinary levels may be higher in diabetic patients due to higher excretion, despite a reduction in blood and scalphair samples compared to nondiabetic controls (Kazi et al. 2008). Retention of dietary manganese may explain why dietary intake and urinary levels of magnesium have the opposite relationship to blood glucose. In fact, higher dietary manganese intake in postmenopausal women is associated with lower diabetes risk, which may also involve factors such as age and/or hormonal status (Gong et al. 2020). Manganese supplementation can increase insulin secretion and lower blood glucose in diet-induced obese mice (Lee et al. 2013). The ability of manganese to increase insulin secretion is linked to manganese superoxide dismutase (MnSOD) and decreased pancreatic oxidative stress, including lipid peroxidation (Lee et al. 2013). Synthetic delivery of manganese can also suppress lipid peroxidation in kidneys and downregulate the expression of genes known to promote diabetic complications such as nephropathy (Khan et al. 2009). Although supplementation can lower oxidative stress in multiple tissue sites, manganese can also increase pancreatic islet amyloid formation, which can inhibit glucose-simulated insulin secretion in vitro (Mirhashemi \& Shahabaddin 2011, Beck et al. 2019). Overall, there is evidence that manganese can promote antioxidant responses that lower blood glucose, but correlations of blood or urinary levels of manganese to blood glucose levels should consider retention and excretion of this micronutrient.

Along with iron and selenium, low levels of manganese determined by hair analyses are associated with newly 
diagnosed IBD suggesting insufficiency in these trace elements are correlated with intestinal inflammation (Cho $\&$ Yang 2018). In mice, manganese promotes the integrity of the intestinal barrier independent of alterations in the gut microbial profile (Choi et al. 2020). Manganese deficiency promotes increased morbidity, weight loss, and colon injury associated with increased inflammatory cytokine levels and oxidative/DNA damage during dextran sulfate sodium (DSS)-induced colitis in mice (Choi et al. 2020). High manganese exposure in male rats lowered gut bacterial richness, $\beta$-hydropyruvic acid, and urocanic acid while increasing tryptamine and taurodeoxycholic acid. Fecal microbial transfer from healthy donors to manganese exposed rats increased bacterial diversity and mitigated manganese-induced neurotoxicity and apoptosis (Wang etal.2020). Dietary manganese can lower the alpha diversity of the gut microbiome in both male and female mice, but sex may modify how manganese alters other aspects of the gut microbiota (Fig. 3). Female mice exposed to manganese had higher Bacteroidetes and Verrucomicrobia and lower
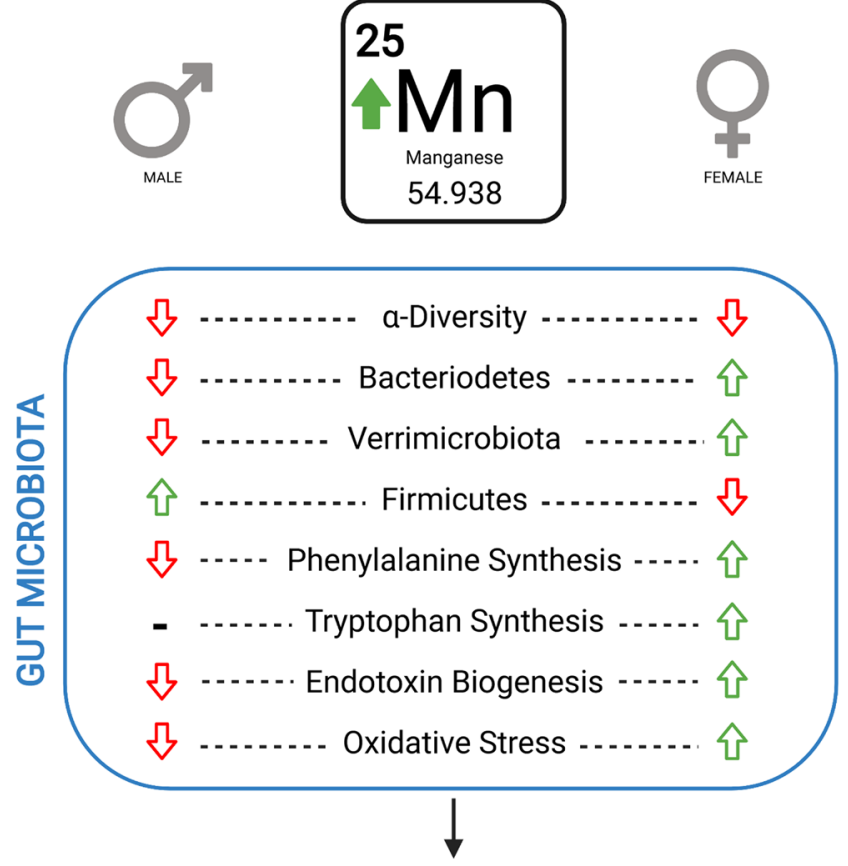

\section{Pancreatic Insulin Secretion}

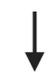

\section{$\checkmark$ Blood Glucose}

\section{Figure 3}

Sex-dependent changes to the gut microbiota are induced by dietary manganese, which may enhance pancreatic insulin secretion and blood glucose regulation. Image created with BioRender.com.
Firmicutes, while male mice had lower Bacteroidetes and Verrucomicrobia and higher Firmicutes. Manganese exposure was associated with higher markers of tryptophan and phenylalanine synthesis in the gut microbiota of female mice, but phenylalanine synthesis was lower in male mice exposed to manganese. In addition, gut bacterial genes involved in endotoxin biogenesis, including Kdo2lipid A synthesis and LPS assembly were decreased in the microbiota of male mice exposed to manganese, which coincided with lower markers of oxidative stress and DNA repair in manganese exposed male mice. However, these manganese-related effects on bacterial endotoxin and host oxidative stress were increased in female mice (Fig. $3)$. Bacterial genes involved in manganese transport and oxidation were increased in female mice but decreased in male mice (Chi et al. 2017). These results suggest that there is a connection between manganese and the host-microbe symbiosis, where sex-specific effects should be considered. It is not yet clear how manganese affects blood glucose via the gut microbiota, but its actions on gut barrier function, inflammation, and oxidative damage could relay signals that alter blood insulin or glucose.

\section{Molybdenum}

Molybdenum mainly acts as an enzymatic cofactor (reviewed in Mehri 2020) and is found in various foods including legumes, whole grains, leafy vegetables, dairy products, eggs, and beef (National Institutes of Health 2020c). Urine molybdenum levels positively correlate with insulin resistance and diabetes status (Menke et al. 2016). However, its mechanisms of action on blood glucose are not clear. Molybdenum supplementation can lower circulating blood glucose and improve glucose tolerance, without increasing insulinemia in insulin-resistant mice (Reul et al. 1997). These results suggest that correlations showing higher molybdenum levels and higher blood glucose do not correspond with mechanistic molybdenum supplementation demonstrating improvements in blood glucose. This discrepancy suggests that the dose of molybdenum and/or excretion/retention of molybdenum are important considerations in the link between this micronutrient and blood glucose. Further, the tissue affected by molybdenum should be considered in any facet of metabolic disease and blood glucose control. Lower circulating concentrations of molybdenum have been associated with increased fatty liver disease (Li et al. 2020), while supplementation can lower hepatic lipids, steatosis, and hepatic oxidative stress in mouse models of fatty liver disease (Lee et al. 2018). 
A high dose of molybdenum (100 mg/kg) lowers the relative abundance of Firmicutes and increases Proteobacteria, Deltaproteobacteria (class), Mytococcales (order), and Nanocystaceae (family) in hens. This altered gut profile induced by molybdenum was associated with lower serum antioxidant measures and increased circulating markers of impaired liver function (alanine transaminase (ALT) and aspartate aminotransferase (AST) (Wang et al. $2019 b$ ). These results suggest the changes in gut microbes correlate with molybdenum-induced effects on liver function.

Molybdenum can also act as a cofactor contributing to gut bacterial enzymatic activity and metabolism. Eggerthella lenta is an enteric bacterial species implicated in drug metabolism. This species requires molybdenum for dopamine dehydroxylation, which metabolizes the medication Levodopa used in Parkinson's disease, preventing dopamine from crossing the blood-brain barrier (Maini Rekdal et al. 2019). Microbial molybdenumcofactor-dependent nitrate respiration and formate dehydrogenation may limit the growth of infectious Enterobacteriaceae, such as Escherichia coli, in inflammationassociated dysbiosis during a murine model of DSS-colitis (Fig. 4). These enzymes require molybdenum to enable metabolic processes critical for pathogenic bacteria to thrive during inflammation (Fig. 4). Administration of tungsten replaces molybdenum thereby inhibiting the molybdopterin cofactor responsible for mitigating E. coli growth. These results demonstrate that molybdenum is an important cofactor in bacterial physiology that can be targeted therapeutically to manipulate the gut microbiota during inflammation-induced dysbiosis (Zhu et al. 2018).

\section{Selenium}

Rich food sources of selenium include seafoods, organ meats, and Pará nuts (National Institutes of Health $2020 d$ ). As a selenoprotein, this trace element is involved mainly in antioxidant defenses and in regulating thyroid function, immunity, and reproduction (reviewed in Mehri 2020). Observational studies demonstrate Vitamins are micronutrients that play a crucial role in theboth deficiency and excess of dietary selenium are associated with insulin resistance and increased risk of diabetes (Yadav et al. 2017, Lu et al. 2019). Multiple randomized controlled trials have tested supplementing selenium in patients with polycystic ovary syndrome, cardiovascular disease, and diabetes, but the effects of supplementation on metabolic parameters such as glucose tolerance, insulin sensitivity, beta-cell function, insulin resistance, and lipid and antioxidant levels are not consistent. However, diabetic coronary heart disease and congestive heart failure patients had lower serum insulin, insulin resistance, circulating LDL cholesterol, C-reactive protein, and higher HDL, and plasma total antioxidant capacity after 8-12 weeks of supplementation with $200 \mu \mathrm{g} /$ day selenised yeast (Farrokhian et al. 2016, Raygan et al. 2018). Selenium supplementation increased insulin sensitivity in diabetic nephropathy patients and pregnant women with gestational diabetes (Asemi et al. 2015, Bahmani et al. 2016). However, selenium supplementation can improve insulin sensitivity some in women with PCOS but promote insulin resistance in other women with PCOS without a clear rationale for the discrepancy (Jamilian et al. 2015, Mohammad Hosseinzadeh et al. 2016), Overall, these results suggest selenium can improve glucose homeostasis, particularly in patients at risk of diabetes or its complications.

As an antioxidant, selenoproteins can mitigate defects in insulin secretion due to oxidative damage in pancreatic beta cells (Li et al. 2015). However, the antioxidant action of selenium can suppress hydrogen-peroxide-mediated insulin signaling (McClung et al. 2004). The hepatokine selenoprotein P facilitates selenium transport in blood, has antioxidant properties, and its circulating levels positively correlate with insulin resistance (Misu et al. 2010). Administration of neutralizing antibodies targeting selenoprotein P improved insulin secretion and glucose

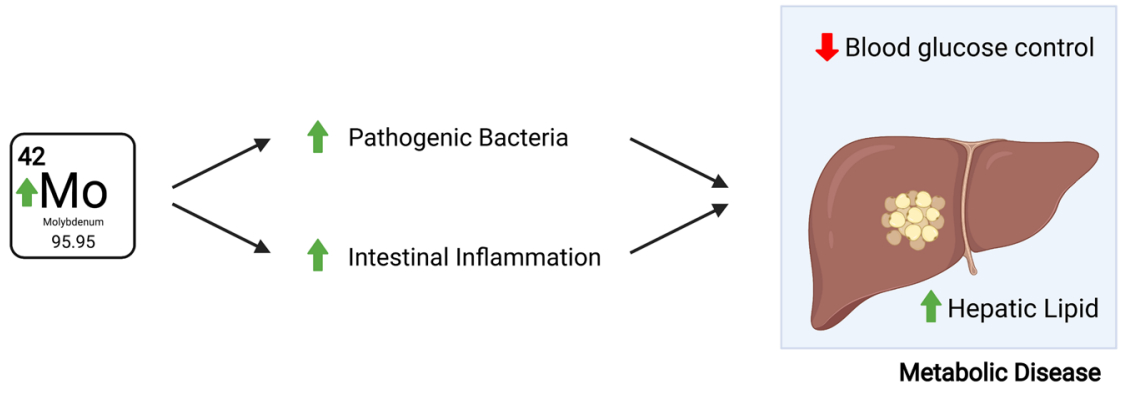

https://joe.bioscientifica.com https://doi.org/10.1530/JOE-21-0081 (c) 2021 Society for Endocrinology Published by Bioscientifica Ltd.
Printed in Great Britain

\section{Figure 4}

Molybdenum promotes the growth of potentially pathogenic bacterial and intestinal inflammation, which may lead to aspects of metabolic disease such as poor glucose control. Image created with BioRender.com. 
sensitivity in type 2 diabetic mouse models, suggesting targeting this specific selenoprotein may provide therapeutic benefits against T2D (Mita et al. 2017).

Circulating levels of selenium are lower in patients with IBD (Stochel-Gaudyn et al. 2019); however, it is not yet clear if the role of selenium on gut inflammation is linked to its metabolic effects. Selenium has been used to limit intestinal pathogens in livestock. Culturing cecal microbiota with selenium nanoparticles lowers the abundance of the poultry pathogen Enterococcus cecorum (Gangadoo et al. 2019). In broiler chickens, organic selenium supplementation increased cecal Lactobacilli spp., while suppressing pathogenic E. coli and Salmonella spp. (Dalia et al. 2018) and selenium-enriched yeast increased bacterial diversity and lowered oxidative stress and inflammation (Yang et al. 2020b).

Selenium-enriched diets increased gut bacterial diversity in mice, which coincides with the decreased relative abundance of Parabacteroides. Mice that harbor microbiota have higher selenium requirements compared to germ-free mice suggesting gut microbes use, biotransform, and compete for selenium with the host (Kasaikina et al. 2011). In addition, gut microbes can regulate selenium through the biotransformation from inorganic to organic states to enhance its bioavailability, as well as methylate excess selenium for excretion to prevent toxicity (Krittaphol et al. 2011, Zhu et al. 2019). Two recent randomized controlled trials examining selenium co-supplementation with a probiotic suggest that combining selenium supplementation with bacterialbased approaches may potentiate its glucose- and insulinlowering effects (Raygan et al. 2019, Tamtaji et al. 2019). Overall, these results demonstrate that a bidirectional relationship between host selenium status and the gut microbiota, which regulates the impact of selenium on host glucose metabolism.

\section{Zinc}

Zinc is an essential mineral found in red meat, poultry, and oysters (National Institutes of Health 2020e). It is involved in many cellular processes including cell division, protein, and DNA synthesis, wound healing, immune function, and is required for the catalytic activity of various enzymes (Mehri 2020). Generally, zinc intake is inversely correlated with T2D risk. A systematic review analyzing 15 original research studies demonstrates that higher zinc status is correlated with lower $\mathrm{HbA1C}$ and that zinc supplementation improved glycemic control in type 2 diabetic patients (de Carvalho et al. 2017). Experiments in rodents demonstrate zinc supplementation improves blood glucose tolerance, insulin secretion indices, and glucose-stimulated insulin secretion in diet-induced obese mice (Cooper-Capetini et al. 2017). Zinc supplementation also lowers insulin resistance, glucose intolerance, and obesity also in obese KKA(y) mice (Adachi et al. 2006). Mechanistically, studies reveal zinc plays a fundamental role in insulin biosynthesis, crystallization, and maturation (Ruz et al. 2019). Zinc also exerts insulinmimetic properties to enhance insulin signaling stimulating GLUT4 translocation and glucose uptake, and by inhibiting the expression of FOXO transcription factors, gluconeogenic enzymes (phosphoenolpyruvate, glucose6-phosphatase), and negative regulators of PI3K/Akt signaling like phosphatase and tensin homolog protein (PTEN) (Cameron et al. 2010, Plum et al. 2014, Wu et al. 2016). Zinc treatment can also suppress NFkB activation and subsequent cytokine production in immune cells, demonstrating its anti-inflammatory properties (von Bülow et al. 2007). Overall, these studies demonstrate an important role for zinc in regulating blood glucose.

Paneth cells located in the small intestine require zinc import to secrete functional antimicrobial granules with bactericidal activity against infectious agents (Podany et al. 2016). Decreased zinc levels are associated with gut inflammatory conditions like IBD (StochelGaudyn et al. 2019). Zinc deficiency enhanced the colonization and bacterial persistence of the pathogen Shigella flexneri in mice, while supplementation promoted resolution of the pathogen-induced inflammation (Q S Medeiros et al. 2019). Zinc supplementation in Salmonella typhimurium exposed broiler chickens reversed markers of ileal apoptosis, impairments in intestinal structure, and increased number of cecal Lactobacillus and total commensal bacteria during infection (Shao et al. 2014). Zinc supplementation may also protect against sepsis by modulating protective immune responses and the gut microbiome, which is reviewed elsewhere (Souffriau \& Libert 2018). It is unclear whether zinc and/or zincinduced antimicrobial peptide production by Paneth cells provide protection against these pathogens in supplemented states. While supplementation may limit some pathogens, excess zinc can promote Clostridium difficile susceptibility and toxin activity in mice, which is associated with lower $\alpha$-diversity, loss of Turicibacter genera, and bloom in Enterococcus and Clostridium genera (Zackular et al. 2016). Excess zinc exposure in neonatal mice is also associated with greater expression https://joe.bioscientifica.com

https://doi.org/10.1530/JOE-21-0081 (c) 2021 Society for Endocrinology Published by Bioscientifica Ltd.
Printed in Great Britain 
of bacterial stress response genes, presence of pathogenic Pseudomonadales and Campylobacter, increased intestinal permeability, and systemic inflammation (Podany et al. 2019). Altogether, these results demonstrate that dietary zinc can influence enteric infections, which may set up for gut inflammation and changes in host metabolism. Zinc-induced changes in blood glucose through changes in commensal bacteria are less clear. One consideration is whether zinc supplementation uses inorganic or organic forms of zinc (Uniyal et al. 2017).

Dietary zinc restriction can increase microbial diversity (Gaulke et al. 2018) or have no effect on the composition of the gut microbiome in mice (Zackular et al. 2016). In broiler chickens, zinc-deficient diets lower cecal microbial species richness and $\alpha$-diversity, along with a lower relative abundance of Firmicutes, and increased Proteobacteria and Enterobacteriaceae. Zinc deficiency resulted in gut bacterial suppression in the expression of pathways involved in mineral (i.e. zinc) absorption, carbohydrate digestion, and fermentation, subsequently leading to decreased SCFA production (Reed et al. 2015). Changes in the gut microbiota due to zinc deficiency correlate with increased intestinal permeability in pregnant mice (Sauer \& Grabrucker 2019). In human Crohn's disease patients, zinc supplementation improved gut barrier function (Sturniolo et al. 2001). Overall, these results demonstrate that dietary zinc deficiency can impair the intestinal barrier, alter gut microbiome processing of carbohydrates, and lower SCFAs production, which may be ways that zinc could influence blood glucose.

\section{Micronutrients: vitamins, gut microbes, and glucose metabolism}

Vitamins are micronutrients that play a crucial role in the homeostasis of eukaryotic and prokaryotic cells. These micronutrients are well-positioned to drive selective pressure in the gut bacterial community and influence aspects of host glucose metabolism. Furthermore, while gut microbes can produce vitamin K, B1 (thiamin), B9 (folic acid), and B12 (cobalamin), they can utilize dietary vitamins and affect their availability to the host. Given their prominent role in glucose homeostasis, in the present review, we examine the role of vitamin A, biotin, and thiamin in blood glucose control and discuss the putative implication of gut commensals. A summary outlining the effects of vitamins on gut bacteria and host metabolism is in Table 4.

\section{Vitamin A}

Vitamin A is an umbrella term that encompasses different types of lipophilic retinoids, such as retinal, retinol, and retinyl esters. Retinoids are known for being essential for vision, maintenance of epithelial integrity, immunological fitness, and reproduction (Coates et al. 2010). Retinoic acid, an oxidized form of Vitamin A, is a key regulator of cell proliferation/differentiation and is essential for the normal growth and development of nearly all tissues in the body (Coates et al. 2010). For this reason, an adequate supply of the dietary precursors of retinoic acid is essential throughout the life span, from early in embryonic development to old age. The liver is the most important site for the storage of retinoic acid precursors in the form of retinyl esters and retinol, which can provide substrates for retinoic acid synthesis for long periods of time without the necessity of daily vitamin A intake. Dietary vitamin A can be obtained as preformed vitamin A (retinol and its esterified form, retinyl ester) and provitamin A (carotenoids). After absorption in the small intestine, both forms undergo intracellular enzymatic transformation to yield several metabolites, of which 11-cis-retinaldehyde and all-trans-retinoic acid (here referred to as retinoic acid) are the major active forms. While the former is critical to normal eyesight function, the latter binds to the nuclear receptor retinoic acid receptor (RAR), which, after dimerization with retinoid X receptor (RXR), binds to retinoic acid-responsive elements (RARE) and regulates several transcriptional programs in various tissues (Coates et al. 2010).

Studies using pre-clinical animal models of vitamin A deficiency demonstrate the role of retinoic acid in glucose homeostasis. Lecithin acyltransferase null mice that have a very low storage capacity of retinoids have lower pancreatic $\beta$-cell mass insulin secretion defects and blood glucose intolerance when fed a diet low in vitamin A. These metabolic defects were corrected with the reintroduction of vitamin A back into the diet (Trasino et al. 2015a). There are several pieces of evidence from pre-clinical obesity models and in vitro analysis suggesting that vitamin A supplementation can improve insulin sensitivity (Bonet et al. 2012). However, vitamin A supplementation appears to alter insulin sensitivity indirectly through lower visceral fat mass accumulation, which has been mechanistically linked to the enhanced thermogenic programs in white and brown adipocytes and higher fat oxidation (Bonet et al. 2012). The role of vitamin A supplementation as an insulin sensitizer acting independently of changes in fat mass warrants further clarification. 
Table 4 The effects of vitamins on the gut microbiome and host metabolism.

\begin{tabular}{|c|c|c|c|}
\hline Vitamin & $\begin{array}{l}\text { Recommended dietary } \\
\text { allowance (RDA) }\end{array}$ & Effects on gut microbiome & Effects on metabolism \\
\hline Vitamin A & $\begin{array}{l}\text { Male: } 900 \mu g \text { * RAE } \\
\text { Female: } 700 \mu g \text { * RAE } \\
\text { Pregnant: } 770 \mu g \text { * RAE } \\
\text { Lactation: } 1300 \mu g \text { * RAE }\end{array}$ & $\begin{array}{l}\text { Clostridiales } \dashv \text { Retinoic acid } \rightarrow I L-22 \rightarrow \text { Antimicrobial } \\
\text { responses in intestinal epithelial cells } \\
\text { Dysbiosis } \rightarrow \uparrow \text { Proteobacteria } \rightarrow \downarrow \text { Retinoic acid } \rightarrow \uparrow S \text {. } \\
\text { typhiumurium colonization } \\
\text { Germ Free vs Conventional Mice: } \\
\text { Retinol/retinoic acid: } \uparrow \text { small intestine, } \downarrow \text { liver } \\
\text { Deficiency: promotes Dysbiosis } \rightarrow \downarrow \text { butyrate producers } \\
\text { (genera Clostridium + Roseburia) } \rightarrow \text { gut } \\
\text { inflammation }+ \text { damage gut barrier integrity } \rightarrow \text { impairs } \\
\text { insulin sensitivity and blood glucose regulation }\end{array}$ & $\begin{array}{l}\text { Deficiency: } \\
\text { glucose intolerance } \\
\text { suboptimal insulin } \\
\text { response, } \uparrow \text { beta cell } \\
\text { apoptosis } \downarrow \text { beta cell mass } \\
\text { Supplementation: } \\
\text { } \text { insulin sensitivity, } \\
\downarrow \text { visceral adiposity } \\
\text { Obese mice: } \downarrow \text { retinol in } \\
\text { tissues vs lean } \\
\uparrow \text { Retinol binding protein } \\
\text { (RBP1) in T2DM and obesity }\end{array}$ \\
\hline $\begin{array}{l}\text { Thiamin } \\
\text { (Vit. B1) }\end{array}$ & $\begin{array}{l}\text { Male: } 1.2 \mathrm{mg} \\
\text { Female: } 1.1 \mathrm{mg} \\
\text { Pregnant: } 1.4 \mathrm{mg} \\
\text { Lactation: } 1.4 \mathrm{mg}\end{array}$ & $\begin{array}{l}\text { Produced by colonic bacteria, like Bacteriodes } \\
\text { Enterobacteriaceae negative association to fecal thiamin, } \\
\text { associated with hyperglycemia independent of obesity }\end{array}$ & $\begin{array}{l}\text { Required for optimal insulin } \\
\text { secretion } \\
\text { Low circulating levels and } \\
\text { lack of transporter } \\
\text { associated with diabetes } \\
\text { Supplementation: } \\
\text { improves glucose } \\
\text { tolerance, } \downarrow \text { fasting blood } \\
\text { glucose }\end{array}$ \\
\hline $\begin{array}{l}\text { Biotin } \\
\text { (Vit. B7) }\end{array}$ & $\begin{array}{l}\text { Male: } 30 \mu g \wedge \\
\text { Female: } 30 \mu g^{\wedge} \\
\text { Pregnant: } 30 \mu g \wedge \\
\text { Lactation: } 35 \mu g \wedge\end{array}$ & $\begin{array}{l}\text { Vancomycin+Biotin Deprivation } \rightarrow \text { Dybiosis } \rightarrow \text { Alopecia } \\
\text { Higher intake } \rightarrow \text { Specific Taxonomic features } \rightarrow \text { Correlate } \\
\text { with lower visceral fat mass }\end{array}$ & $\begin{array}{l}\text { Cofactor for mammalian } \\
\text { carboxylases } \\
\text { Pharmacological doses } \\
\text { lower blood glucose } \\
\text { Deficiency: } \\
\text { lowers glucose utilization } \\
\text { and lipogenesis }\end{array}$ \\
\hline
\end{tabular}

RDA values based on adults aged 19-50 years old.

*Vitamin A RDA values are given as retinol activity equivalents (RAE) to account for bioactivity differences of retinol and provitamin A carotenoids, which are then converted into vitamin A. ^Adequate intake (Al) values are given for Biotin.

In murine models of diet- and genetic-induced obesity, lower levels of retinol was found in various tissues, whereas serum retinol was higher in obese mice compared to lean controls (Trasino et al. 2015b). This suggests vitamin A deficiency may be associated with defective tissue uptake/ delivery and can occur regardless of adequate dietary intake of vitamin A during obesity. Indeed, higher retinolbinding protein (RBP1) has been observed in humans with T2D and obesity (Mody 2017). How the findings from preclinical animal studies and cross-sectional human analysis described above translate into feasible treatment strategies against obesity and insulin resistance require further investigation. A phase 2 double-blind randomized clinical trial to test the effect of the synthetic retinoid fenretinide on insulin resistance is underway (Chojkier 2013).

Glucose homeostasis is governed by immunometabolic processes where innate and adaptive immune responses alter insulin sensitivity and blood glucose (Anhê et al. $2020 b$ ). The gut barrier is an important component of innate immunity as it selectively segregates environmental antigens from inner body compartments. Gut dysbiosis- driven perturbations to the gut barrier homeostasis are linked to poor glycemic control and insulin resistance (Winer et al. 2017). Retinoic acid is instrumental for multiple innate and adaptive immune responses, including lymphocyte activation/proliferation, $\mathrm{T}$ helper (Th) cell differentiation, tissue-specific lymphocyte homing, and the production of specific antibody isotypes (Larange \& Cheroutre 2016). Specifically, reduction of intestinal Th17 cells occurs in mice fed a vitamin A-deficient highfat diet, which correlates to worsened metabolic outcomes such as increased weight gain, glucose intolerance, and insulin resistance (Hong et al. 2017). This T cell subset can profoundly influence gut microbes, promoting the expansion of commensal bacteria associated with leanness, as demonstrated in hematopoietic cell adoptive-transfer experiments (Hong et al. 2017). These results demonstrate how vitamin A can influence host-microbe interactions. In the gut, retinoic acid influences mucosal immunity, eliciting both regulatory and pro-inflammatory responses depending on its concentration and intestinal infectious context (Erkelens \& Mebius 2017) (Fig. 5). Gut commensals, 
particularly Clostridiales, can downregulate the synthesis of retinoic acid in intestinal epithelial cells, which lowers IL-22 secretion to ensure resolution of antimicrobial responses clear pathogenic bacteria in the gut (Grizotte-Lake et al. 2018). However, during vancomycin-driven gut dysbiosis marked by overexpansion of Proteobacteria, the capacity of gut microbes to relay signals to the host via reduced retinoic acid synthesis is compromised, which promotes colonization by pathogens such as Salmonella typhimurium (Grizotte-Lake et al. 2018). Gut commensal-related regulation of retinoic acid synthesis may be controlled by specific taxa that grow in response to a particular infection since IL-22 is required to clear certain pathobionts from the intestine (Wang et al. 2014). In addition, inhibition of retinoic acid synthesis by Clostridiales in the gut likely does not restrain the availability of retinoic acid to other organs, otherwise, it would drive hyperglycemia, which per se would damage the gut barrier integrity and ease colonization by pathogens (Thaiss et al. 2018). Indeed, while germ-free mice display a higher retinol/retinoic acid ratio in the small intestine compared to mice that harbor a microbiota, the opposite was observed in the liver (Grizotte-Lake et al. 2018). Therefore, the net effect of commensal gut microbes is to favor the storage of hepatic retinol, which facilitates normal glucose metabolism. It is also interesting to note that the dysmetabolism seen in murine vitamin A deficiency models is associated with a substantial reduction in butyrate producers from the genera Clostridium and Roseburia (Tian et al. 2018). Low butyrate production is linked to a more pro-inflammatory milieu in the gut and damaged gut barrier integrity (De Vadder et al. 2014), which impairs insulin sensitivity and blood glucose regulation. In addition to more robust human trials testing vitamin $\mathrm{A}$ as an insulin sensitizer, an important knowledge gap to be filled is how gut microbes tip the balance of retinoic acid synthesis/storage to ensure adequate enteric antimicrobial response and metabolic control at once.

\section{Biotin}

Biotin is classified as a B-complex vitamin also known as vitamin B7. Biotin is positioned to alter glucose metabolism because it acts as a cofactor for five mammalian carboxylases involved in the tricarboxylic acid cycle (TCA) cycle: pyruvate carboxylase, propionyl-CoA carboxylase, methylcrotonyl-CoA carboxylase, and two isoforms of acetyl-CoA carboxylase. Biotin is present in animalbased diets and in vegetables such as cauliflower and spinach. It is most often protein-bound, thus requiring intestinal hydrolysis prior to absorption. As a water-soluble molecule, biotin cannot freely cross the membrane of enterocytes, and therefore, absorption occurs via the sodium-dependent multivitamin transporter. Biotin absorption takes place in the small intestine and in the proximal colon, which positions biotin to interact with commensals and influence host-microbe relationship that alters metabolism (Said 2004). In accordance, recent large-scale metagenomic analysis has shown that the gut microbiota is linked to both synthesis and degradation of B vitamins (Visconti et al. 2019).

Pharmacological doses of biotin can lower blood glucose and mitigate other aspects of metabolic syndrome (Aguilera-Mendez et al. 2018). Accordingly, pre-clinical studies suggest that biotin deficiency is linked to lower glucose utilization and lipogenesis in parallel to increased gluconeogenic and fat oxidation programs (VelazquezArellano et al. 2011). Altogether these studies suggest that an adequate dietary intake of biotin is important to maintain euglycemia, and that biotin supplementation may have a value as an adjuvant in the treatment of T2D. If gut commensals influence host blood glucose by altering biotin availability remains to be elucidated. It is known from murine models that vancomycin-driven dysbiosis, when coupled with biotin deprivation, leads to hair loss (Hayashi et al. 2017). The fact that dysbiosis and biotin deprivation, alone, were not sufficient to cause alopecia suggests that the gut microbiota can generate enough biotin to affect host physiology (Fig. 5). In agreement, higher biotin intake requires specific taxonomic features in the fecal microbiota to correlate with lower visceral fat mass (Le Roy et al. 2019). These findings suggest that gut commensals may mediate the impact of biotin on host blood glucose control at least in part by influencing the buildup of visceral fat (Fig. 5).

\section{Thiamin}

Thiamin, or vitamin B1, was the first B-complex watersoluble vitamin described. This vitamin plays an essential role in cellular growth and development, energy metabolism, and oxidative stress (Coates et al. 2010). Thiamin is predominantly obtained from the diet but can be synthesized by gut commensals. Free thiamin crosses the gut barrier through specialized transporters located both at the apical and basolateral sides of enterocytes in the proximal small intestine (Said 2011). Thiamin pyrophosphate is the metabolically active form and acts as a cofactor for enzymes involved in carbohydrate metabolism. Thiamin deficiency is linked to neurological 


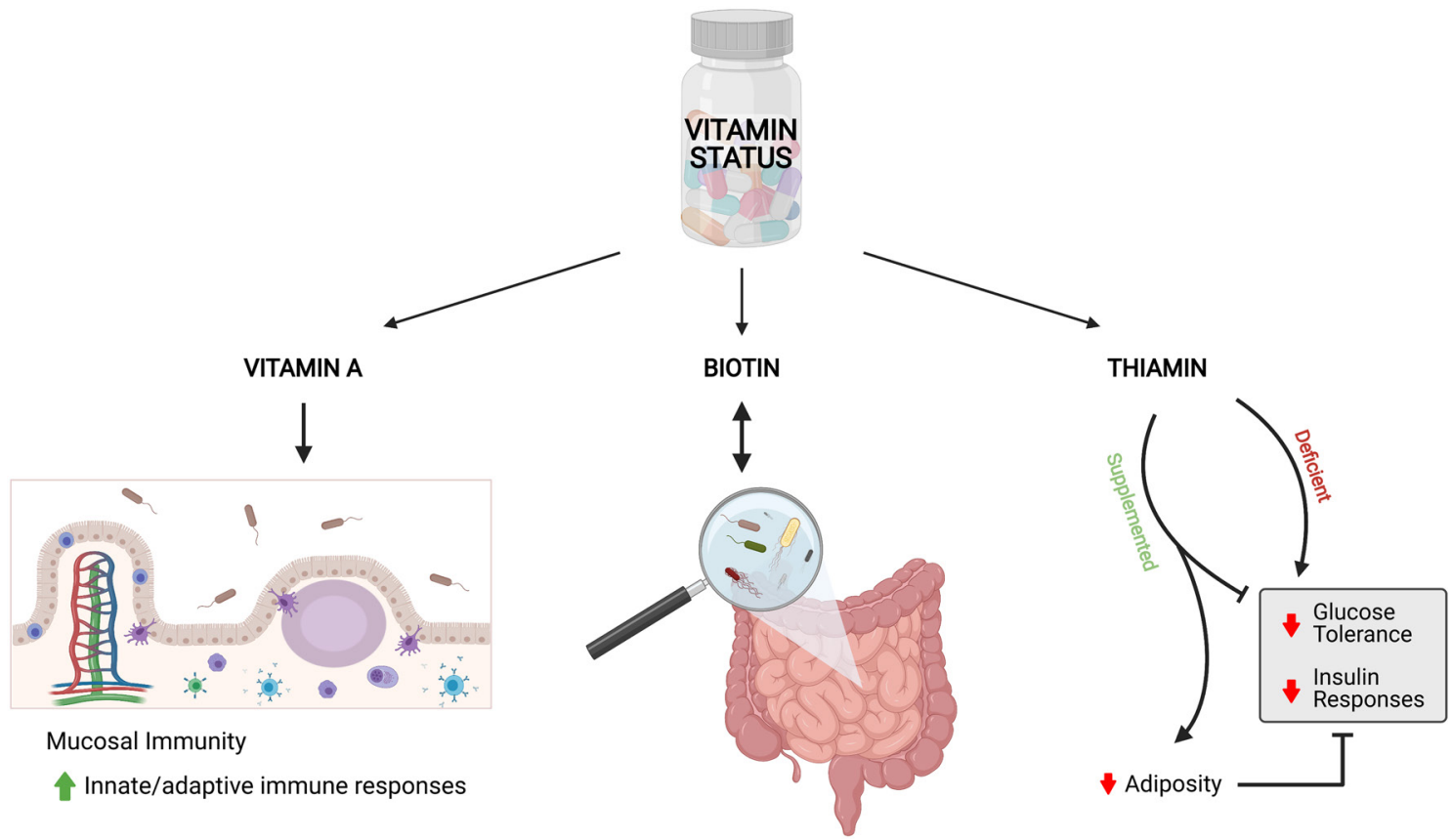

Figure 5

Gut microbes can influence host vitamin status and metabolic health. Image created with BioRender.com.

and cardiovascular diseases. Low intracellular levels of thiamin lead to apoptosis and oxidative stress, which is a common node in diabetic complications such as retinopathy and nephropathy, and neurological disorders (Page et al. 2011).

Thiamin is necessary for optimal insulin secretion by pancreatic $\beta$-cells (Rathanaswami \& Sundaresan 1991). Indeed, lack of a functional thiamin transporter leads to diabetes in humans (Neufeld et al. 2001), whereas reduced plasma thiamin has been found in patients with diabetes (Thornalley et al. 2007). In addition to its role in $\beta$-cell physiology, thiamin deficiency leads to suboptimal activity of key enzymes in carbohydrate metabolism, which ultimately favors the buildup of glucotoxic intermediates linked to endothelial complications associated with hyperglycemia (Page et al. 2011). Since the 1940s thiamin supplementation has been shown to improve glucose tolerance and fasting blood glucose (Kaufman 1940) (Fig. 5). These findings have been corroborated more recently and extended to an important beneficial effect of thiamin supplementation on vascular health and oxidative stress in the context of hyperglycemia (Stirban et al. 2006).

The amount of absorbable thiamin is regulated by the microbiota and produced by colonic bacteria (Magnúsdóttir et al. 2015). Although dietary thiamin is predominantly absorbed in the small intestine, colonocytes also possess the functional membrane transporters necessary for thiamin absorption(Said etal. 2001). This suggests that gutmicrobialderived thiamin in the distal gut is positioned to contribute to host thiamin levels and regulate host metabolism (Fig. 5). A recent study using Drosophila melanogaster showed that thiamin derived from the gut microbiota is sufficient and necessary to support host physiology in a low-thiamin environment (Sannino et al. 2018). How the gut microbiota affects the pool of active thiamin in the host during obesity or metabolic disease is not yet clear. Certain bacteria, such as Bacteroides, can biosynthesize thiamin, whereas others, such as Alistipes and Bacilli, may rely entirely on crossfeeding and/or dietary thiamin (Costliow \& Degnan 2017). Thiamin intake may be used as an important selective advantage by certain bacteria, with potential consequences to the host thiamin load. Furthermore, intestinal dysbiosis may be associated with the selection of bacteria that can only transport thiamin to the detriment of producers, which may contribute to lower thiamin availability to the host. The presence of the Enterobacteriaceae member E. coli in the fecal microbiota of humans was found to be negatively correlated with fecal thiamin (Visconti et al. 2019). Interestingly, certain Enterobacteriaceae are linked to higher blood glucose independently of obesity (Thingholm et al. 2019, Anhê et al. 2020a). Further research is needed to test the hypothesis that members of the Enterobacteriaceae 
family contribute to lower thiamin - and perhaps other B-vitamins - availability to the host, and whether this could be one of the mechanisms by which these bacteria can deteriorate blood glucose control in the host.

\section{Conclusions}

Micronutrients, including trace elements and vitamins, interact with the gut microbiota to influence host glucose metabolism. Micronutrients can alter the composition of the intestinal bacteria and commensal microbes influence micronutrient bioavailability. Differences in the source, duration, and experimental models preclude generalizations on the metabolic effects of supplementation of each micronutrient. In addition, characterizing microbial signatures and microbial function at different sites along the gastrointestinal tract, specifically the small intestine where a majority of nutrients are metabolized, would provide further insight into how micronutrients alter glycemia through hostmicrobe interactions. However, dietary deficiency or excess of nearly every micronutrient compromised host blood glucose metabolism. There has been a focus on macronutrients and the host-microbe relationship in metabolic disease, where carefully controlled mechanistic studies are revealing the role of fat, carbohydrates, and protein in glucose metabolism. Dietary fiber is a key factor, and we propose that dietary micronutrients should be considered in the host-microbe symbiosis relevant to blood glucose control.

\section{Declaration of interest}

The authors declare that there is no conflict of interest that could be perceived as prejudicing the impartiality of this review. Dr Jonathan Schertzer is a Senior Editor of Journal of Endocrinology. Dr Schertzer was not involved in the review or editorial process for this paper, on which he is listed as an author.

\section{Funding}

This work was supported by grants to J D S from the Canadian Institutes of Health Research (FDN-154295). J D S holds a Canada Research Chair in Metabolic Inflammation.

\section{Author contribution statement}

N G B, F F A and J D S wrote the manuscript. All authors edited the manuscript.

\section{References}

Adachi Y, Yoshida J, Kodera Y, Kiss T, Jakusch T, Enyedy EA, Yoshikawa Y \& Sakurai H 2006 Oral administration of a zinc complex improves type 2 diabetes and metabolic syndromes. Biochemical and Biophysical Research Communications 351 165-170. (https://doi.org/10.1016/j. bbrc.2006.10.014)

Aguilar MJ, González-Jiménez E, Antelo A \& Perona JS 2013 Insulin resistance and inflammation markers: correlations in obese adolescents. Journal of Clinical Nursing 22 2002-2010. (https://doi. org/10.1111/jocn.12034)

Aguilera-Mendez A, Hernandez-Equihua MG, Rueda-Rocha AC, GuajardoLopez C, Nieto-Aguilar R, Serrato-Ochoa D, Herrera LFR \& GuzmánNateras JA 2018 Protective effect of supplementation with biotin against high-fructose-induced metabolic syndrome in rats. Nutrition Research 57 86-96. (https://doi.org/10.1016/j.nutres.2018.06.007)

Anhê FF, Jensen BAH, Varin TV, Servant F, Van Blerk S, Richard D, Marceau S, Surette M, Biertho L, Lelouvier B, et al. 2020a Type 2 diabetes influences bacterial tissue compartmentalisation in human obesity. Nature Metabolism 2 233-242. (https://doi.org/10.1038/s42255020-0178-9)

Anhê FF, Barra NG \& Schertzer JD $2020 b$ Glucose alters the symbiotic relationships between gut microbiota and host physiology. American Journal of Physiology: Endocrinology and Metabolism 318 E111-E116. (https://doi.org/10.1152/ajpendo.00485.2019)

Asemi Z, Jamilian M, Mesdaghinia E \& Esmaillzadeh A 2015 Effects of selenium supplementation on glucose homeostasis, inflammation, and oxidative stress in gestational diabetes: randomized, doubleblind, placebo-controlled trial. Nutrition 31 1235-1242. (https://doi. org/10.1016/j.nut.2015.04.014)

Bäckhed F, Ding H, Wang T, Hooper LV, Koh GY, Nagy A, Semenkovich CF \& Gordon JI 2004 The gut microbiota as an environmental factor that regulates fat storage. PNAS 101 15718-15723. (https://doi.org/10.1073/ pnas.0407076101)

Bäckhed F, Manchester JK, Semenkovich CF \& Gordon JI 2007 Mechanisms underlying the resistance to diet-induced obesity in germ-free mice. PNAS 104 979-984. (https://doi.org/10.1073/pnas.0605374104)

Bahmani F, Kia M, Soleimani A, Asemi Z \& Esmaillzadeh A 2016 Effect of selenium supplementation on glycemic control and lipid profiles in patients with diabetic nephropathy. Biological Trace Element Research 172 282-289. (https://doi.org/10.1007/s12011-015-0600-4)

Beck R, Chandi M, Kanke M, Stýblo M \& Sethupathy P 2019 Arsenic is more potent than cadmium or manganese in disrupting the INS-1 beta cell microRNA landscape. Archives of Toxicology 93 3099-3109. (https://doi. org/10.1007/s00204-019-02574-8)

Bisanz JE, Upadhyay V, Turnbaugh JA, Ly K \& Turnbaugh PJ 2019 Metaanalysis reveals reproducible gut microbiome alterations in response to a high-fat diet. Cell Host and Microbe 26 265-272.e4. (https://doi. org/10.1016/j.chom.2019.06.013)

Bonet ML, Ribot J \& Palou A 2012 Lipid metabolism in mammalian tissues and its control by retinoic acid. Biochimica et Biophysica Acta 1821 177-189. (https://doi.org/10.1016/j.bbalip.2011.06.001)

Cameron AR, Anil S, Sutherland E, Harthill J \& Rena G 2010 Zincdependent effects of small molecules on the insulin-sensitive transcription factor FOXO1a and gluconeogenic genes. Metallomics 2 195-203. (https://doi.org/10.1039/b914984h)

Cândido FG, Valente FX, Grześkowiak ŁM, Moreira APB, Rocha DMUP \& Alfenas RCG de 2018 Impact of dietary fat on gut microbiota and lowgrade systemic inflammation: mechanisms and clinical implications on obesity. International Journal of Food Sciences and Nutrition 69 125-143. (https://doi.org/10.1080/09637486.2017.1343286)

Chassard C \& Lacroix C 2013 Carbohydrates and the human gut microbiota. Current Opinion in Clinical Nutrition and Metabolic Care 16 453-460. (https://doi.org/10.1097/MCO.0b013e3283619e63)

Chen WY, Chen CJ, Liu CH \& Mao FC 2010 Chromium attenuates highfat diet-induced nonalcoholic fatty liver disease in KK/HlJ mice. 
Biochemical and Biophysical Research Communications 397 459-464. (https://doi.org/10.1016/j.bbrc.2010.05.129)

Chi L, Gao B, Bian X, Tu P, Ru H \& Lu K 2017 Manganese-induced sexspecific gut microbiome perturbations in C57BL/6 mice. Toxicology and Applied Pharmacology 331 142-153. (https://doi.org/10.1016/j. taap.2017.06.008)

Chiba FY, Colombo NH, Shirakashi DJ, da Silva VC, Moimaz SAS, Garbin CAS, Antoniali C \& Sumida DH 2012 NaF treatment increases TNF- $\alpha$ and resistin concentrations and reduces insulin signal in rats. Journal of Fluorine Chemistry 136 3-7. (https://doi.org/10.1016/j. jfluchem.2011.12.006)

Cho JM \& Yang HR 2018 Hair mineral and trace element contents as reliable markers of nutritional status compared to serum levels of these elements in children newly diagnosed with inflammatory bowel disease. Biological Trace Element Research 185 20-29. (https://doi. org/10.1007/s12011-017-1225-6)

Cho I, Yamanishi S, Cox L, Methé BA, Zavadil J, Li K, Gao Z, Mahana D, Raju K, Teitler I, et al. 2012 Antibiotics in early life alter the murine colonic microbiome and adiposity. Nature 488 621-626. (available at: http://www.nature.com/nature/journal/v488/n7413/abs/nature11 400.html\#supplementary-information) (https://doi.org/10.1038/ nature11400)

Choi EK, Aring L, Das NK, Solanki S, Inohara N, Iwase S, Samuelson LC, Shah YM \& Seo YA 2020 Impact of dietary manganese on experimenta colitis in mice. FASEB Journal 34 2929-2943. (https://doi.org/10.1096/ fj.201902396R)

Chojkier M 2013 A randomized, double-blind study of the effects of fenretinide administered in subjects with obesity. ClinicalTrials.gov Identifier: NCT00546455 (available at https://clinicaltrials.gov/ct2/ show/NCT00546455)

Coates PM, Betz JM, Blackman MR, Cragg GM, Levine M, Moss J \& White JD 2010 Encyclopedia of Dietary Supplements, 2nd ed. Taylor \& Francis.

Cooper-Capetini V, de Vasconcelos DAA, Martins AR, Hirabara SM, Donato J, Carpinelli AR \& Abdulkader F 2017 Zinc supplementation improves glucose homeostasis in high fat-fed mice by enhancing pancreatic $\beta$-cell function. Nutrients 9 1150. (https://doi.org/10.3390/ nu9101150)

Costliow ZA \& Degnan PH 2017 Thiamine acquisition strategies impact metabolism and competition in the gut microbe bacteroides thetaiotaomicron. mSystems 2 e00116-17. (https://doi.org/10.1128/ mSystems.00116-17)

Cox LM, Yamanishi S, Sohn J, Alekseyenko AV, Leung JM, Cho I, Kim SG, Li H, Gao Z, Mahana D, et al. 2014 Altering the intestinal microbiota during a critical developmental window has lasting metabolic consequences. Cell 158 705-721. (https://doi.org/10.1016/j. cell.2014.05.052)

Dalby MJ, Ross AW, Walker AW \& Morgan PJ 2017 Dietary uncoupling of gut microbiota and energy harvesting from obesity and glucose tolerance in mice. Cell Reports 21 1521-1533. (https://doi.org/10.1016/j. celrep.2017.10.056)

Dalia AM, Loh TC, Sazili AQ, Jahromi MF \& Samsudin AA 2018 Effects of vitamin E, inorganic selenium, bacterial organic selenium, and their combinations on immunity response in broiler chickens. BMC Veterinary Research 14 249. (https://doi.org/10.1186/s12917-0181578-x)

David LA, Maurice CF, Carmody RN, Gootenberg DB, Button JE, Wolfe BE, Ling AV, Devlin AS, Varma Y, Fischbach MA, et al. 2014 Diet rapidly and reproducibly alters the human gut microbiome. Nature 505 559-563. (https://doi.org/10.1038/nature12820)

de Carvalho GB, Brandão-Lima PN, Maia CSC, Barbosa KBF \& Pires LV 2017 Zinc's role in the glycemic control of patients with type 2 diabetes: a systematic review. Biometals 30 151-162. (https://doi.org/10.1007/ s10534-017-9996-y)

De Vadder F, Kovatcheva-Datchary P, Goncalves D, Vinera J, Zitoun C, Duchampt A, Bäckhed F \& Mithieux G 2014 Microbiota-generated metabolites promote metabolic benefits via gut-brain neural circuits. Cell 156 84-96. (https://doi.org/10.1016/j.cell.2013.12.016)

Di Giancamillo A, Rossi R, Martino PA, Aidos L, Maghin F, Domeneghini C \& Corino C 2018 Copper sulphate forms in piglet diets: microbiota, intestinal morphology and enteric nervous system glial cells. Animal Science Journal 89 616-624. (https://doi.org/10.1111/ asj.12948)

Erkelens MN \& Mebius RE 2017 Retinoic acid and immune homeostasis: a balancing act. Trends in Immunology 38 168-180. (https://doi. org/10.1016/j.it.2016.12.006)

Fan Y, Zhang C \& Bu J 2017 Relationship between selected serum metallic elements and obesity in children and adolescent in the U.S. Nutrients 9 104. (https://doi.org/10.3390/nu9020104)

Farrokhian A, Bahmani F, Taghizadeh M, Mirhashemi SM, Aarabi MH, Raygan F, Aghadavod E \& Asemi Z 2016 Selenium supplementation affects insulin resistance and serum hs-CRP in patients with type 2 diabetes and coronary heart disease. Hormone and Metabolic Research 48 263-268. (https://doi.org/10.1055/s-0035-1569276)

Feng W, Zhao T, Mao G, Wang W, Feng Y, Li F, Zheng D, Wu H, Jin D, Yang L, et al. 2015 Type 2 diabetic rats on diet supplemented with chromium malate show improved glycometabolism, glycometabolismrelated enzyme levels and lipid metabolism. PLOS ONE 10 e0125952. (https://doi.org/10.1371/journal.pone.0125952)

Foley KP, Zlitni S, Denou E, Duggan BM, Chan RW, Stearns JC \& Schertzer JD 2018 Long term but not short term exposure to obesity related microbiota promotes host insulin resistance. Nature Communications 9 4681. (https://doi.org/10.1038/s41467-018-07146-5)

Follin-Arbelet B \& Moum B 2016 Fluoride: a risk factor for inflammatory bowel disease? Scandinavian Journal of Gastroenterology 51 1019-1024 (https://doi.org/10.1080/00365521.2016.1177855)

Gangadoo S, Bauer BW, Bajagai YS, Van TTH, Moore RJ \& Stanley D 2019 In vitro growth of gut microbiota with selenium nanoparticles. Animal Nutrition 5 424-431. (https://doi.org/10.1016/j.aninu.2019.06.004)

Gaulke CA, Rolshoven J, Wong CP, Hudson LG, Ho E \& Sharpton TJ 2018 Marginal zinc deficiency and environmentally relevant concentrations of arsenic elicit combined effects on the gut microbiome. mSphere 3 e00521-18. (https://doi.org/10.1128/mSphere.00521-18)

Gérard P 2016 Gut microbiota and obesity. Cellular and Molecular Life Sciences 73 147-162. (https://doi.org/10.1007/s00018-015-2061-5)

Gong JH, Lo K, Liu Q, Li J, Lai S, Shadyab AH, Arcan C, Snetselaar L \& Liu S 2020 Dietary manganese, plasma markers of inflammation, and the development of type 2 diabetes in postmenopausal women: findings from the Women's Health Initiative. Diabetes Care 43 1344-1351. (https://doi.org/10.2337/dc20-0243)

Grizotte-Lake M, Zhong G, Duncan K, Kirkwood J, Iyer N, Smolenski I, Isoherranen N \& Vaishnava S 2018 Commensals suppress intestinal epithelial cell retinoic acid synthesis to regulate interleukin-22 activity and prevent microbial dysbiosis. Immunity 49 1103.e6-1115.e6. (https:// doi.org/10.1016/j.immuni.2018.11.018)

Han XY, Du WL, Fan CL \& Xu ZR 2010 Changes in composition a metabolism of caecal microbiota in rats fed diets supplemented with copper-loaded chitosan nanoparticles. Journal of Animal Physiology and Animal Nutrition 94 e138-e144. (https://doi.org/10.1111/j.14390396.2010.00995.x)

Hayashi A, Mikami Y, Miyamoto K, Kamada N, Sato T, Mizuno S, Naganuma M, Teratani T, Aoki R, Fukuda S, et al. 2017 Intestinal dysbiosis and biotin deprivation induce alopecia through overgrowth of Lactobacillus murinus in mice. Cell Reports 20 1513-1524. (https:// doi.org/10.1016/j.celrep.2017.07.057)

Hong CP, Park A, Yang BG, Yun CH, Kwak MJ, Lee GW, Kim JH, Jang MS, Lee EJ, Jeun EJ, et al. 2017 Gut-specific delivery of T-helper 17 cells reduces obesity and insulin resistance in mice. Gastroenterology 152 1998-2010. (https://doi.org/10.1053/j.gastro.2017.02.016)

Horning KJ, Caito SW, Tipps KG, Bowman AB \& Aschner M 2015 Manganese is essential for neuronal health. Annual Review of Nutrition 35 71-108. (https://doi.org/10.1146/annurev-nutr-071714-034419) https://joe.bioscientifica.com

https://doi.org/10.1530/JOE-21-0081 (c) 2021 Society for Endocrinology Published by Bioscientifica Ltd. Printed in Great Britain 
Huang H, Chen G, Dong Y, Zhu Y \& Chen H 2018 Chromium supplementation for adjuvant treatment of type 2 diabetes mellitus: results from a pooled analysis. Molecular Nutrition and Food Research 62 28677892. (https://doi.org/10.1002/mnfr.201700438)

Jamilian M, Razavi M, Fakhrie Kashan Z, Ghandi Y, Bagherian T \& Asemi Z 2015 Metabolic response to selenium supplementation in women with polycystic ovary syndrome: a randomized, double-blind, placebocontrolled trial. Clinical Endocrinology 82 885-891. (https://doi. org/10.1111/cen.12699)

Jensen BAH, Holm JB, Larsen IS, von Burg N, Derer S, Sonne SB, Pærregaard SI, Damgaard MV, Indrelid SA, Rivollier A, et al. 2021 Lysates of methylococcus capsulatus bath induce a lean-like microbiota, intestinal FoxP3+ROR $\gamma \mathrm{t}+\mathrm{IL}-17+$ Tregs and improve metabolism. Nature Communications 12 1093. (https://doi.org/10.1038/s41467-021-21408-9)

Karakaya RE, Saka M \& Ozdemir D 2020 Determining the relationship between dietary iodine intake, urinary iodine excretion and thyroid functions in people with type 2 diabetes mellitus. Archives of Endocrinology and Metabolism 64 383-389. (https://doi. org/10.20945/2359-3997000000233)

Kasaikina MV, Kravtsova MA, Lee BC, Seravalli J, Peterson DA, Walter J, Legge R, Benson AK, Hatfield DL \& Gladyshev VN 2011 Dietary selenium affects host selenoproteome expression by influencing the gut microbiota. FASEB Journal 25 2492-2499. (https://doi.org/10.1096/ fj.11-181990)

Kaufman RE 1940 Influence of thiamine on blood sugar levels in diabetic patients. Archives of Internal Medicine 66 1079-1086. (https://doi. org/10.1001/archinte.1940.00190170070004)

Kazi TG, Afridi HI, Kazi N, Jamali MK, Arain MB, Jalbani N \& Kandhro GA 2008 Copper, chromium, manganese, iron, nickel, and zinc levels in biological samples of diabetes mellitus patients. Biological Trace Element Research 122 1-18. (https://doi.org/10.1007/s12011-007-8062-y)

Khan I, Batinic-Haberle I \& Benov LT 2009 Effect of potent redoxmodulating manganese porphyrin, MnTM-2-PyP, on the $\mathrm{Na}(+) / \mathrm{H}(+)$ exchangers NHE-1 and NHE-3 in the diabetic rat. Redox Report: Communications in Free Radical Research 14 236-242. (https://doi.org/10 $.1179 / 135100009 X 12525712409698)$

Krittaphol W, McDowell A, Thomson CD, Mikov M \& Fawcett JP 2011 Biotransformation of L-selenomethionine and selenite in rat gut contents. Biological Trace Element Research 139 188-196. (https://doi. org/10.1007/s12011-010-8653-x)

Larange A \& Cheroutre H 2016 Retinoic acid and retinoic acid receptors as pleiotropic modulators of the immune system. Annual Review of Immunology 34 369-394. (https://doi.org/10.1146/annurevimmunol-041015-055427)

Le Roy CI, Bowyer RCE, Castillo-Fernandez JE, Pallister T, Menni C, Steves CJ, Berry SE, Spector TD \& Bell JT 2019 Dissecting the role of the gut microbiota and diet on visceral fat mass accumulation. Scientific Reports 9 9758. (https://doi.org/10.1038/s41598-019-46193-w)

Lee SH, Jouihan HA, Cooksey RC, Jones D, Kim HJ, Winge DR \& McClain DA 2013 Manganese supplementation protects against dietinduced diabetes in wild type mice by enhancing insulin secretion. Endocrinology 154 1029-1038. (https://doi.org/10.1210/en.2012-1445)

Lee S, Nam KH, Seong JK \& Ryu DY 2018 Molybdate attenuates lipid accumulation in the livers of mice fed a diet deficient in methionine and choline. Biological and Pharmaceutical Bulletin 41 1203-1210. (https://doi.org/10.1248/bpb.b18-00020)

Li XL, Wong YS, Xu G \& Chan JCN 2015 Selenium-enriched spirulina protects INS-1E pancreatic beta cells from human islet amyloid polypeptide-induced apoptosis through suppression of ROS-mediated mitochondrial dysfunction and PI3/AKT pathway. European Journal of Nutrition 54 509-522. (https://doi.org/10.1007/s00394-014-0732-x)

Li L, Huang L, Huang S, Luo X, Zhang H, Mo Z, Wu T \& Yang X 2020 Nonlinear association of serum molybdenum and linear association of serum zinc with nonalcoholic fatty liver disease: multiple-exposure and Mendelian randomization approach. Science of the Total Environment 720 137655. (https://doi.org/10.1016/j.scitotenv.2020.137655)
Liu G, Wang B, Huang Y, Li K, Ge W, Zhang M, Yue B \& Kong M 2019a The growth rate, immune status, duodenal development, and cecal microbial diversity of 24-day-old offspring of SD rats received Bacillus subtilis-Cu or CuSO4 during pregnancy and lactation periods. Biological Trace Element Research 191 435-442. (https://doi.org/10.1007/s12011-019-1638-5)

Liu J, Wang HW, Lin L, Miao CY, Zhang Y \& Zhou BH $2019 b$ Intestinal barrier damage involved in intestinal microflora changes in fluorideinduced mice. Chemosphere 234 409-418. (https://doi.org/10.1016/j. chemosphere.2019.06.080)

Lobo JGVM, Leite AL, Pereira HABS, Fernandes MS, Peres-Buzalaf C, Sumida DH, Rigalli A \& Buzalaf MAR 2015 Low-level fluoride exposure increases insulin sensitivity in experimental diabetes. Journal of Dental Research 94 990-997. (https://doi. org/10.1177/0022034515581186)

Lu CW, Chang HH, Yang KC, Chiang CH, Yao CA \& Huang KC 2019 Gender differences with dose-response relationship between serum selenium levels and metabolic syndrome - a case control study. Nutrients 11477. (https://doi.org/10.3390/nu11020477)

Lykstad J \& Sharma S 2020 Biochemistry, Water Soluble Vitamins. Treasure Island (FL): StatPearls.

Magnúsdóttir S, Ravcheev D, de Crécy-Lagard V \& Thiele I 2015 Systematic genome assessment of B-vitamin biosynthesis suggests co-operation among gut microbes. Frontiers in Genetics 6 148. (https://doi. org/10.3389/fgene.2015.00148)

Maini Rekdal V, Bess EN, Bisanz JE, Turnbaugh PJ \& Balskus EP 2019 Discovery and inhibition of an interspecies gut bacterial pathway for levodopa metabolism. Science $\mathbf{3 6 4}$ eaau6323. (https://doi.org/10.1126/ science.aau6323)

Makki K, Deehan EC, Walter J \& Bäckhed F 2018 The impact of dietary fiber on gut microbiota in host health and disease. Cell Host and Microbe 23 705-715. (https://doi.org/10.1016/j.chom.2018.05.012)

Mancini FR, Rajaobelina K, Dow C, Habbal T, Affret A, Balkau B, Bonnet F, Boutron-Ruault MC \& Fagherazzi G 2019 High iodine dietary intake is associated with type 2 diabetes among women of the E3N-EPIC cohort study. Clinical Nutrition 38 1651-1656. (https://doi.org/10.1016/j. clnu.2018.08.015)

Maratou E, Hadjidakis DJ, Kollias A, Tsegka K, Peppa M, Alevizaki M Mitrou P, Lambadiari V, Boutati E, Nikzas D, et al. 2009 Studies of insulin resistance in patients with clinical and subclinical hypothyroidism. European Journal of Endocrinology 160 785-790. (https://doi.org/10.1530/EJE-08-0797)

Maratou E, Hadjidakis DJ, Peppa M, Alevizaki M, Tsegka K, Lambadiari V, Mitrou P, Boutati E, Kollias A, Economopoulos T, et al. 2010 Studies of insulin resistance in patients with clinical and subclinical hyperthyroidism. European Journal of Endocrinology 163 625-630. (https://doi.org/10.1530/EJE-10-0246)

McClung JP, Roneker CA, Mu W, Lisk DJ, Langlais P, Liu F \& Lei XG 2004 Development of insulin resistance and obesity in mice overexpressing cellular glutathione peroxidase. PNAS 101 8852-8857. (https://doi. org/10.1073/pnas.0308096101)

McCreight LJ, Bailey CJ \& Pearson ER 2016 Metformin and the gastrointestinal tract. Diabetologia 59 426-435. (https://doi. org/10.1007/s00125-015-3844-9)

Mehri A 2020 Trace elements in human nutrition (II) - an update. International Journal of Preventive Medicine 11 2. (https://doi. org/10.4103/ijpvm.IJPVM_48_19)

Meng XL, Li S, Qin CB, Zhu ZX, Hu WP, Yang LP, Lu RH, Li WJ \& Nie GX 2018 Intestinal microbiota and lipid metabolism responses in the common carp (Cyprinus carpio L.) following copper exposure. Ecotoxicology and Environmental Safety 160 257-264. (https://doi. org/10.1016/j.ecoenv.2018.05.050)

Menke A, Guallar E \& Cowie CC 2016 Metals in urine and diabetes in U.S. adults. Diabetes 65 164-171. (https://doi.org/10.2337/db15-0316)

Miao L, Gong Y, Li H, Xie C, Xu Q, Dong X, Elwan HAM \& Zou X 2020 Alterations in cecal microbiota and intestinal barrier function of laying hens fed on fluoride supplemented diets. Ecotoxicology https://joe.bioscientifica.com https://doi.org/10.1530/JOE-21-0081 (c) 2021 Society for Endocrinology Published by Bioscientifica Ltd. Printed in Great Britain 
and Environmental Safety 193 110372. (https://doi.org/10.1016/j. ecoenv.2020.110372)

Miller GD, Keen CL, Stern JS \& Uriu-Hare JY 1998 Copper deficiency and arachidonic acid enhance insulin secretion in isolated pancreatic islets from lean (FaFa) zucker rats. Pancreas 17 390-396. (https://doi. org/10.1097/00006676-199811000-00010)

Mirhashemi SM \& Shahabaddin ME 2011 Evaluation of aluminium, manganese, copper and selenium effects on human islets amyloid polypeptide hormone aggregation. Pakistan Journal of Biological Sciences 14 288-292. (https://doi.org/10.3923/pjbs.2011.288.292)

Misu H, Takamura T, Takayama H, Hayashi H, Matsuzawa-Nagata N, Kurita S, Ishikura K, Ando H, Takeshita Y, Ota T, et al. 2010 A liver-derived secretory protein, selenoprotein $\mathrm{P}$, causes insulin resistance. Cell Metabolism 12 483-495. (https://doi.org/10.1016/j. cmet.2010.09.015)

Mita Y, Nakayama K, Inari S, Nishito Y, Yoshioka Y, Sakai N, Sotani K, Nagamura T, Kuzuhara Y, Inagaki K, et al. 2017 Selenoprotein P-neutralizing antibodies improve insulin secretion and glucose sensitivity in type 2 diabetes mouse models. Nature Communications 8 1658. (https://doi.org/10.1038/s41467-017-01863-z)

Mody N 2017 Alterations in vitamin A/retinoic acid homeostasis in dietinduced obesity and insulin resistance. Proceedings of the Nutrition Society 76 597-602. (https://doi.org/10.1017/S0029665117001069)

Mohammad Hosseinzadeh F, Hosseinzadeh-Attar MJ, Yekaninejad MS \& Rashidi B 2016 Effects of selenium supplementation on glucose homeostasis and free androgen index in women with polycystic ovary syndrome: a randomized, double blinded, placebo controlled clinical trial. Journal of Trace Elements in Medicine and Biology 34 56-61. (https:// doi.org/10.1016/j.jtemb.2016.01.002)

National Institutes of Health 2019 Copper: Fact Sheet for Consumers. Bethesda, MD, USA: USA.gov.

National Institutes of Health 2020a Chromium: Dietary Supplemental Fact Sheet. Bethesda, MD, USA: USA.gov.

National Institutes of Health 2020b Iodine: Fact Sheet for Health Professionals. Bethesda, MD, USA: USA.gov.

National Institutes of Health 2020c Molybdenum: Fact Sheet for Health Professionals. Bethesda, MD, USA: USA.gov.

National Institutes of Health 2020d Selenium: Fact Sheet for Health Professionals. Bethesda, MD, USA: USA.gov.

National Institutes of Health 2020e Zinc: Fact Sheet for Health Professionals. Bethesda, MD, USA: USA.gov.

Neufeld EJ, Fleming JC, Tartaglini E \& Steinkamp MP 2001 Thiamineresponsive megaloblastic anemia syndrome: a disorder of high-affinity thiamine transport. Blood Cells, Molecules and Diseases 27 135-138. (https://doi.org/10.1006/bcmd.2000.0356)

Page GLJ, Laight D \& Cummings MH 2011 Thiamine deficiency in diabetes mellitus and the impact of thiamine replacement on glucose metabolism and vascular disease. International Journal of Clinical Practice 65 684-690. (https://doi.org/10.1111/j.1742-1241.2011.02680.x)

Paiva AN, Lima JG, Medeiros AC, Figueiredo HA, Andrade RL, Ururahy MA, Rezende AA, Brandão-Neto J \& Almeida Md 2015 Beneficial effects of oral chromium picolinate supplementation on glycemic control in patients with type 2 diabetes: a randomized clinical study. Journal of Trace Elements in Medicine and Biology 32 66-72. (https://doi. org/10.1016/j.jtemb.2015.05.006)

Pedersen HK, Gudmundsdottir V, Nielsen HB, Hyotylainen T, Nielsen T, Jensen BAH, Forslund K, Hildebrand F, Prifti E, Falony G, et al. 2016 Human gut microbes impact host serum metabolome and insulin sensitivity. Nature 535 376-381. (https://doi.org/10.1038/nature18646)

Piacenza F, Malavolta M, Basso A, Costarelli L, Giacconi R, Ravussin E, Redman LM \& Mocchegiani E 2015 Effect of 6-month caloric restriction on $\mathrm{Cu}$ bound to ceruloplasmin in adult overweight subjects. Journal of Nutritional Biochemistry 26 876-882. (https://doi.org/10.1016/j. jnutbio.2015.03.012)

Plum LM, Brieger A, Engelhardt G, Hebel S, Nessel A, Arlt M, Kaltenberg J, Schwaneberg U, Huber M, Rink L, et al. 2014 PTEN-inhibition by zinc ions augments interleukin-2-mediated Akt phosphorylation. Metallomics 6 1277-1287. (https://doi.org/10.1039/c3mt00197k)

Podany AB, Wright J, Lamendella R, Soybel DI \& Kelleher SL 2016 ZnT2mediated zinc import into Paneth cell granules is necessary for coordinated secretion and Paneth cell function in mice. Cellular and Molecular Gastroenterology and Hepatology 2 369-383. (https://doi. org/10.1016/j.jcmgh.2015.12.006)

Podany A, Rauchut J, Wu T, Kawasawa YI, Wright J, Lamendella R, Soybel DI $\&$ Kelleher SL 2019 Excess dietary zinc intake in neonatal mice causes oxidative stress and alters intestinal host-microbe interactions. Molecular Nutrition and Food Research 63 e1800947. (https://doi. org/10.1002/mnfr.201800947)

Q S Medeiros PH, Ledwaba SE, Bolick DT, Giallourou N, Yum LK, Costa DVS, Oriá RB, Barry EM, Swann JR, Lima AÂM, et al. 2019 A murine model of diarrhea, growth impairment and metabolic disturbances with Shigella flexneri infection and the role of zinc deficiency. Gut Microbes $\mathbf{1 0}$ 615-630. (https://doi.org/10.1080/19490976.2018.1564430)

Rathanaswami P \& Sundaresan R 1991 Effects of thiamine deficiency on the biosynthesis of insulin in rats. Biochemistry International $\mathbf{2 4}$ 1057-1062.

Raygan F, Behnejad M, Ostadmohammadi V, Bahmani F, Mansournia MA, Karamali F \& Asemi Z 2018 Selenium supplementation lowers insulin resistance and markers of cardio-metabolic risk in patients with congestive heart failure: a randomised, double-blind, placebocontrolled trial. British Journal of Nutrition 120 33-40. (https://doi. org/10.1017/S0007114518001253)

Raygan F, Ostadmohammadi V \& Asemi Z 2019 The effects of probiotic and selenium co-supplementation on mental health parameters and metabolic profiles in type 2 diabetic patients with coronary heart disease: a randomized, double-blind, placebo-controlled trial. Clinical Nutrition 38 1594-1598. (https://doi.org/10.1016/j.clnu.2018.07.017)

Reed S, Neuman H, Moscovich S, Glahn RP, Koren O \& Tako E 2015 Chronic zinc deficiency alters chick gut microbiota composition and function. Nutrients 7 9768-9784. (https://doi.org/10.3390/nu7125497)

Reul BA, Becker DJ, Ongemba LN, Bailey CJ, Henquin JC \& Brichard SM 1997 Improvement of glucose homeostasis and hepatic insulin resistance in ob/ob mice given oral molybdate. Journal of Endocrinology 155 55-64. (https://doi.org/10.1677/joe.0.1550055)

Rinninella E, Cintoni M, Raoul P, Lopetuso LR, Scaldaferri F, Pulcini G, Miggiano GAD, Gasbarrini A \& Mele MC 2019 Food components and dietary habits: keys for a healthy gut microbiota composition. Nutrients 11 2393. (https://doi.org/10.3390/nu11102393)

Ruan Y, Wu C, Guo X, Xu Z, Xing C, Cao H, Zhang C, Hu G \& Liu P 2019 High doses of copper and mercury changed cecal microbiota in female mice. Biological Trace Element Research 189 134-144. (https://doi. org/10.1007/s12011-018-1456-1)

Ruz M, Carrasco F, Rojas P, Basfi-Fer K, Hernández MC \& Pérez A 2019 Nutritional effects of zinc on metabolic syndrome and type 2 diabetes: mechanisms and main findings in human studies. Biological Trace Element Research 188 177-188. (https://doi.org/10.1007/s12011-0181611-8)

Said HM 2004 Recent advances in carrier-mediated intestinal absorption of water-soluble vitamins. Annual Review of Physiology 66 419-446. (https://doi.org/10.1146/annurev.physiol.66.032102.144611)

Said HM 2011 Intestinal absorption of water-soluble vitamins in health and disease. Biochemical Journal 437 357-372. (https://doi.org/10.1042/ BJ20110326)

Said HM, Ortiz A, Subramanian VS, Neufeld EJ, Moyer MP \& Dudeja PK 2001 Mechanism of thiamine uptake by human colonocytes: studies with cultured colonic epithelial cell line NCM460. American Journal of Physiology: Gastrointestinal and Liver Physiology 281 G144-G150. (https://doi.org/10.1152/ajpgi.2001.281.1.G144)

Samadi R, Ghanbari M, Shafiei B, Gheibi S, Azizi F \& Ghasemi A 2017 High dose of radioactive iodine per se has no effect on glucose metabolism in thyroidectomized rats. Endocrine 56 399-407. (https://doi.org/10.1007/ s12020-017-1274-9) https://joe.bioscientifica.com https://doi.org/10.1530/JOE-21-0081 (c) 2021 Society for Endocrinology Published by Bioscientifica Ltd. Printed in Great Britain 
Sannino DR, Dobson AJ, Edwards K, Angert ER \& Buchon N 2018 The Drosophila melanogaster gut microbiota provisions thiamine to its host. mBio 9 e00155-18. (https://doi.org/10.1128/mBio.00155-18)

Sarkar D, Chakraborty A, Saha A \& Chandra AK 2018 Iodine in excess in the alterations of carbohydrate and lipid metabolic pattern as well as histomorphometric changes in associated organs. Journal of Basic and Clinical Physiology and Pharmacology 29 631-643. (https://doi. org/10.1515/jbcpp-2017-0204)

Sauer AK \& Grabrucker AM 2019 Zinc deficiency during pregnancy leads to altered microbiome and elevated inflammatory markers in mice. Frontiers in Neuroscience 13 1295. (https://doi.org/10.3389/ fnins.2019.01295)

Seal M \& Dey SG 2018 Active-site environment of copper-bound human amylin relevant to Type 2 diabetes. Inorganic Chemistry 57 129-138. (https://doi.org/10.1021/acs.inorgchem.7b02266)

Shan Z, Chen S, Sun T, Luo C, Guo Y, Yu X, Yang W, Hu FB \& Liu L 2016 $\mathrm{U}$-shaped association between plasma manganese levels and type 2 diabetes. Environmental Health Perspectives 124 1876-1881. (https://doi. org/10.1289/EHP176)

Shao Y, Lei Z, Yuan J, Yang Y, Guo Y \& Zhang B 2014 Effect of zinc on growth performance, gut morphometry, and cecal microbial community in broilers challenged with Salmonella enterica serovar typhimurium. Journal of Microbiology 52 1002-1011. (https://doi. org/10.1007/s12275-014-4347-y)

Sharma A, Kapoor D, Wang J, Shahzad B, Kumar V, Bali AS, Jasrotia S, Zheng B, Yuan H \& Yan D 2020 Chromium bioaccumulation and its impacts on plants: an overview. Plants 9 100. (https://doi.org/10.3390/ plants9010100)

Shen W, Gaskins HR \& McIntosh MK 2014 Influence of dietary fat on intestinal microbes, inflammation, barrier function and metabolic outcomes. Journal of Nutritional Biochemistry 25 270-280. (https://doi. org/10.1016/j.jnutbio.2013.09.009)

Shen H, Han J, Li Y, Lu C, Zhou J, Li Y \& Su X 2019 Different host-specific responses in thyroid function and gut microbiota modulation between diet-induced obese and normal mice given the same dose of iodine. Applied Microbiology and Biotechnology 103 3537-3547. (https://doi. org/10.1007/s00253-019-09687-1)

Sitasawad S, Deshpande M, Katdare M, Tirth S \& Parab P 2001 Beneficial effect of supplementation with copper sulfate on STZ-diabetic mice (IDDM). Diabetes Research and Clinical Practice 52 77-84. (https://doi. org/10.1016/s0168-8227(00)00249-7)

Song M, Li X, Zhang X, Shi H, Vos MB, Wei X, Wang Y, Gao H, Rouchka EC, Yin X, et al. 2018 Dietary copper-fructose interactions alter gut microbial activity in male rats. American Journal of Physiology: Gastrointestinal and Liver Physiology 314 G119-G130. (https://doi. org/10.1152/ajpgi.00378.2016)

Souffriau J \& Libert C 2018 Mechanistic insights into the protective impact of zinc on sepsis. Cytokine and Growth Factor Reviews 39 92-101. (https://doi.org/10.1016/j.cytogfr.2017.12.002)

Stirban A, Negrean M, Stratmann B, Gawlowski T, Horstmann T, Götting C, Kleesiek K, Mueller-Roesel M, Koschinsky T, Uribarri J, et al. 2006 Benfotiamine prevents macro-and microvascular endothelial dysfunction and oxidative stress following a meal rich in advanced glycation end products in individuals with type 2 diabetes. Diabetes Care 29 2064-2071. (https://doi.org/10.2337/dc06-0531)

Stochel-Gaudyn A, Fyderek K \& Kościelniak P 2019 Serum trace elements profile in the pediatric inflammatory bowel disease progress evaluation. Journal of Trace Elements in Medicine and Biology 55 121-126. (https://doi.org/10.1016/j.jtemb.2019.06.016)

Sturniolo GC, Di Leo V, Ferronato A, D'Odorico A \& D'Incà R 2001 Zinc supplementation tightens 'leaky gut' in Crohn's disease. Inflammatory Bowel Diseases 7 94-98. (https://doi.org/10.1097/00054725-200105000 00003)

Sun Z, Wang X, Chen J, Duan P, Wang J, Liu Y \& Guo H 2017 Effects of iodine excess on islet $\beta$ cells( $\beta$-TC-6) function and the mechanism. Wei Sheng Yan Jiu 46 610-614.
Tamtaji OR, Heidari-Soureshjani R, Mirhosseini N, Kouchaki E, Bahmani F, Aghadavod E, Tajabadi-Ebrahimi M \& Asemi Z 2019 Probiotic and selenium co-supplementation, and the effects on clinical, metabolic and genetic status in Alzheimer's disease: a randomized, doubleblind, controlled trial. Clinical Nutrition 38 2569-2575. (https://doi. org/10.1016/j.clnu.2018.11.034)

Thaiss CA, Levy M, Grosheva I, Zheng D, Soffer E, Blacher E, Braverman S, Tengeler AC, Barak O, Elazar M, et al. 2018 Hyperglycemia drives intestinal barrier dysfunction and risk for enteric infection. Science 359 1376-1383. (https://doi.org/10.1126/science.aar3318)

Thingholm LB, Rühlemann MC, Koch M, Fuqua B, Laucke G, Boehm R, Bang C, Franzosa EA, Hübenthal M, Rahnavard A, et al. 2019 Obese individuals with and without Type 2 diabetes show different gut microbial functional capacity and composition. Cell Host and Microbe 26 252.e10-264.e10. (https://doi.org/10.1016/j.chom.2019.07.004)

Thornalley PJ, Babaei-Jadidi R, Al Ali H, Rabbani N, Antonysunil A Larkin J, Ahmed A, Rayman G \& Bodmer CW 2007 High prevalence of low plasma thiamine concentration in diabetes linked to a marker of vascular disease. Diabetologia 50 2164-2170. (https://doi.org/10.1007/ s00125-007-0771-4)

Thursby E \& Juge N 2017 Introduction to the human gut microbiota. Biochemical Journal 474 1823-1836. (https://doi.org/10.1042/ BCJ20160510)

Tian Y, Nichols RG, Cai J, Patterson AD \& Cantorna MT 2018 Vitamin A deficiency in mice alters host and gut microbial metabolism leading to altered energy homeostasis. Journal of Nutritional Biochemistry $\mathbf{5 4}$ 28-34. (https://doi.org/10.1016/j.jnutbio.2017.10.011)

Trasino SE, Benoit YD \& Gudas LJ 2015a Vitamin A deficiency causes hyperglycemia and loss of pancreatic $\beta$-cell mass. Journal of Biological Chemistry 290 1456-1473. (https://doi.org/10.1074/jbc.M114.616763)

Trasino SE, Tang XH, Jessurun J \& Gudas LJ 2015b Obesity leads to tissue, but not serum vitamin A deficiency. Scientific Reports 5 15893. (https:// doi.org/10.1038/srep15893)

Trevizol JS, Buzalaf NR, Dionizio A, Delgado AQ, Cestari TM, Bosqueiro JR, Magalhães AC \& Buzalaf MAR 2020 Effects of low-level fluoride exposure on glucose homeostasis in female NOD mice. Chemosphere 254 126602. (https://doi.org/10.1016/j. chemosphere.2020.126602)

Uniyal S, Garg AK, Jadhav SE, Chaturvedi VK \& Mohanta RK 2017 Comparative efficacy of zinc supplementation from different sources on nutrient digestibility, hemato-biochemistry and anti-oxidant activity in guinea pigs. Livestock Science 204 59-64. (https://doi. org/10.1016/j.livsci.2017.08.009)

Vallianou NG, Stratigou T \& Tsagarakis S 2019 Metformin and gut microbiota: their interactions and their impact on diabetes. Hormones 18 141-144. (https://doi.org/10.1007/s42000-019-00093-w)

Velazquez-Arellano A, Ortega-Cuellar D, Hernandez-Mendoza A \& MorenoArriola E 2011 A heuristic model for paradoxical effects of biotin starvation on carbon metabolism genes in the presence of abundant glucose. Molecular Genetics and Metabolism 102 69-77. (https://doi. org/10.1016/j.ymgme.2010.08.021)

Visconti A, Le Roy CI, Rosa F, Rossi N, Martin TC, Mohney RP, Li W, de Rinaldis E, Bell JT, Venter JC, et al. 2019 Interplay between the human gut microbiome and host metabolism. Nature Communications 104505. (https://doi.org/10.1038/s41467-019-12476-z)

von Bülow V, Dubben S, Engelhardt G, Hebel S, Plümäkers B, Heine H, Rink L \& Haase H 2007 Zinc-dependent suppression of TNF-alpha production is mediated by protein kinase A-induced inhibition of Raf-1, I kappa B kinase beta, and NF-kappa B. Journal of Immunology 179 4180-4186. (https://doi.org/10.4049/jimmunol.179.6.4180)

Wang X, Ota N, Manzanillo P, Kates L, Zavala-Solorio J, Eidenschenk C, Zhang J, Lesch J, Lee WP, Ross J, et al. 2014 Interleukin-22 alleviates metabolic disorders and restores mucosal immunity in diabetes. Nature 514 237-241. (https://doi.org/10.1038/nature13564)

Wang T, Wei X, Chen T, Wang W, Xia X, Miao J \& Yin S 2019a Studies of the mechanism of fatty liver formation in Takifugu fasciatus following 
copper exposure. Ecotoxicology and Environmental Safety 181 353-361. (https://doi.org/10.1016/j.ecoenv.2019.06.013)

Wang J, Yang Z, Celi P, Yan L, Ding X, Bai S, Zeng Q, Mao X, Feng B, Xu S, et al. $2019 \mathrm{~b}$ Alteration of the antioxidant capacity and gut microbiota under high levels of molybdenum and green tea polyphenols in laying hens. Antioxidants 8 503. (https://doi.org/10.3390/antiox8100503)

Wang H, Zhang S, Yang F, Xin R, Wang S, Cui D \& Sun Y 2020 The gut microbiota confers protection in the CNS against neurodegeneration induced by manganism. Biomedicine and Pharmacotherapy 127110150. (https://doi.org/10.1016/j.biopha.2020.110150)

Ward B, Walker K \& Exley C 2008 Copper(II) inhibits the formation of amylin amyloid in vitro. Journal of Inorganic Biochemistry 102 371-375. (https://doi.org/10.1016/j.jinorgbio.2007.09.010)

Wei X, Song M, Yin X, Schuschke DA, Koo I, McClain CJ \& Zhang X 2015 Effects of dietary different doses of copper and high fructose feeding on rat fecal metabolome. Journal of Proteome Research 14 4050-4058. (https://doi.org/10.1021/acs.jproteome.5b00596)

Whitford GM 1994 Intake and metabolism of fluoride. Advances in Dental Research 8 5-14. (https://doi.org/10.1177/08959374940080011001)

Winer DA, Winer S, Dranse HJ \& Lam TKT 2017 Immunologic impact of the intestine in metabolic disease. Journal of Clinical Investigation $\mathbf{1 2 7}$ 33-42. (https://doi.org/10.1172/JCI88879)

Wu Y, Lu H, Yang H, Li C, Sang Q, Liu X, Liu Y, Wang Y \& Sun Z 2016 Zinc stimulates glucose consumption by modulating the insulin signaling pathway in L6 myotubes: essential roles of Akt-GLUT4, GSK3 $\beta$ and mTOR-S6K1. Journal of Nutritional Biochemistry 34 126-135. (https:// doi.org/10.1016/j.jnutbio.2016.05.008)

Yadav C, Manjrekar PA, Agarwal A, Ahmad A, Hegde A \& Srikantiah RM 2017 Association of serum selenium, zinc and magnesium levels with glycaemic indices and insulin resistance in pre-diabetes: a crosssectional study from South India. Biological Trace Element Research 175 65-71. (https://doi.org/10.1007/s12011-016-0766-4)

Yang J, Xu Y, Qian K, Zhang W, Wu D \& Wang C 2016 Effects of chromiumenriched bacillus subtilis KT260179 supplementation on growth performance, caecal microbiology, tissue chromium level, insulin receptor expression and plasma biochemical profile of mice under heat stress. British Journal of Nutrition 115 774-781. (https://doi.org/10.1017/ S0007114515005127)

Yang J, Yang A, Cheng N, Huang W, Huang P, Liu N \& Bai Y 2020a Sex-specific associations of blood and urinary manganese levels with glucose levels, insulin resistance and kidney function in US adults: National Health and Nutrition Examination Survey 2011-2016. Chemosphere 258 126940. (https://doi.org/10.1016/j. chemosphere.2020.126940)
Yang S, Li L, Yu L, Sun L, Li K, Tong C, Xu W, Cui G, Long M \& Li P 2020 b Selenium-enriched yeast reduces caecal pathological injuries and intervenes changes of the diversity of caecal microbiota caused by Ochratoxin-A in broilers. Food and Chemical Toxicology 137111139. (https://doi.org/10.1016/j.fct.2020.111139)

Yasuda K, Hsu T, Gallini CA, Mclver LJ, Schwager E, Shi A, DuLong CR, Schwager RN, Abu-Ali GS, Franzosa EA, et al. 2017 Fluoride depletes acidogenic taxa in oral but not gut microbial communities in mice. mSystems 2. (https://doi.org/10.1128/mSystems.00047-17)

Yin J, Wang X, Li S, Zhu Y, Chen S, Li P, Luo C, Huang Y, Li X, Hu X, et al. 2019 Interactions between plasma copper concentrations and SOD1 gene polymorphism for impaired glucose regulation and type 2 diabetes. Redox Biology 24 101172. (https://doi.org/10.1016/j. redox.2019.101172)

Zackular JP, Moore JL, Jordan AT, Juttukonda LJ, Noto MJ, Nicholson MR, Crews JD, Semler MW, Zhang Y, Ware LB, et al. 2016 Dietary zinc alters the microbiota and decreases resistance to clostridium difficile infection. Nature Medicine 22 1330-1334. (https://doi.org/10.1038/ nm.4174)

Zhang Q, Sun X, Xiao X, Zheng J, Li M, Yu M, Ping F, Wang Z, Qi C, Wang T, et al. 2016 Maternal chromium restriction leads to glucose metabolism imbalance in mice offspring through insulin signaling and Wnt signaling pathways. International Journal of Molecular Sciences 171767. (https://doi.org/10.3390/ijms17101767)

Zhang F, Zheng W, Xue Y \& Yao W 2019 Suhuai suckling piglet hindgut microbiome-metabolome responses to different dietary copper levels. Applied Microbiology and Biotechnology 103 853-868. (https://doi. org/10.1007/s00253-018-9533-0)

Zhao J, Zhang X, Liu H, Brown MA \& Qiao S 2019 Dietary protein and gut microbiota composition and function. Current Protein and Peptide Science 20 145-154. (https://doi.org/10.2174/138920371966618051414 5437)

Zhu T \& Goodarzi MO 2020 Metabolites linking the gut microbiome with risk for type 2 diabetes. Current Nutrition Reports 9 83-93. (https://doi. org/10.1007/s13668-020-00307-3)

Zhu W, Winter MG, Byndloss MX, Spiga L, Duerkop BA, Hughes ER, Büttner L, de Lima Romão E, Behrendt CL, Lopez CA, et al. 2018 Precision editing of the gut microbiota ameliorates colitis. Nature 553 208-211. (https://doi.org/10.1038/nature25172)

Zhu H, Zhou Y, Qi Y, Ji R, Zhang J, Qian Z, Wu C, Tan J, Shao L \& Chen D 2019 Preparation and characterization of selenium enrichedbifidobacterium longum DD98, and its repairing effects on antibioticinduced intestinal dysbacteriosis in mice. Food and Function 10 4975-4984. (https://doi.org/10.1039/c9fo00960d)

Received in final form 17 May 2021

Accepted 23 June 2021

Accepted Manuscript published online 24 June 2021 (c) 2021 Society for Endocrinology Published by Bioscientifica Ltd. Printed in Great Britain 